\title{
Hot Cell Design and Maintenance
}

Ron Johansen

April 2017

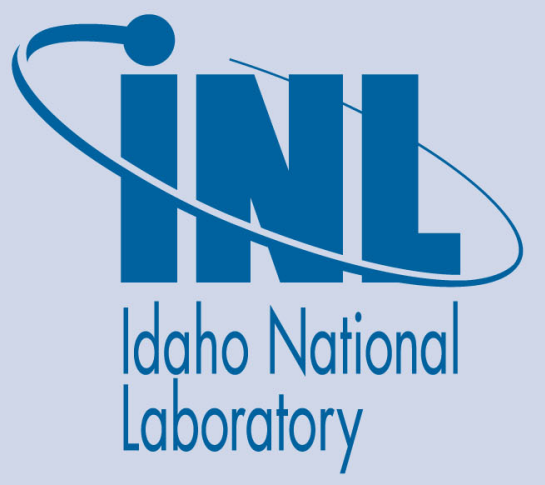

The INL is a U.S. Department of Energy National Laboratory operated by Battelle Energy Alliance 


\title{
Hot Cell Design and Maintenance
}

\author{
Ron Johansen
}

April 2017

Idaho National Laboratory Idaho Falls, Idaho 83415

http://www.inl.gov

Prepared for the

U.S. Department of Energy

Under DOE Idaho Operations Office

Contract DE-AC07-05ID14517 


\title{
MFC Hot Cell Design and Maintenance
}

\author{
Ronald Johansen \\ MFC Facility Engineering \\ INL/MIS-17-41766 Rev 0
}

April 2017 


\section{Presentation Outline}

- Scope

- HFEF Atmosphere Control Systems

- Material Handling Systems Overview

- Overhead Handling System

- Thru Wall Manipulators

- Transfer Systems

- Cask Transfer Systems

- Overhead Handling System Design Features

- Maintenance Support Systems/Areas

- Summary 


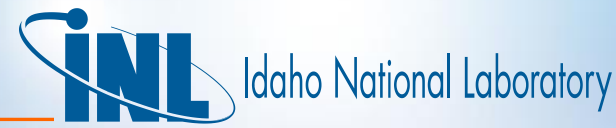

\section{Hot Fuels Examination Facility (HFEF) Overview}

- Main Cell (Argon Atmosphere)

- Concrete shielded, gas tight, steel lined

$-70 \mathrm{ft} \times 30 \mathrm{ft} \times 25 \mathrm{ft} \mathrm{High} \mathrm{(21.3} \mathrm{m} \mathrm{x} 9.1 \mathrm{~m} \times 7.6 \mathrm{~m}$ high)

$-8 \mathrm{ft}(2.4 \mathrm{~m})$ deep space with removable flooring

- Decon Cell (Air Atmosphere)

- Concrete shielded, gas tight, steel lined

$-20 \mathrm{ft} \times 30 \mathrm{ft} \times 25 \mathrm{ft}$ High (6.1 m x 9.1 m x $7.6 \mathrm{~m}$ high)

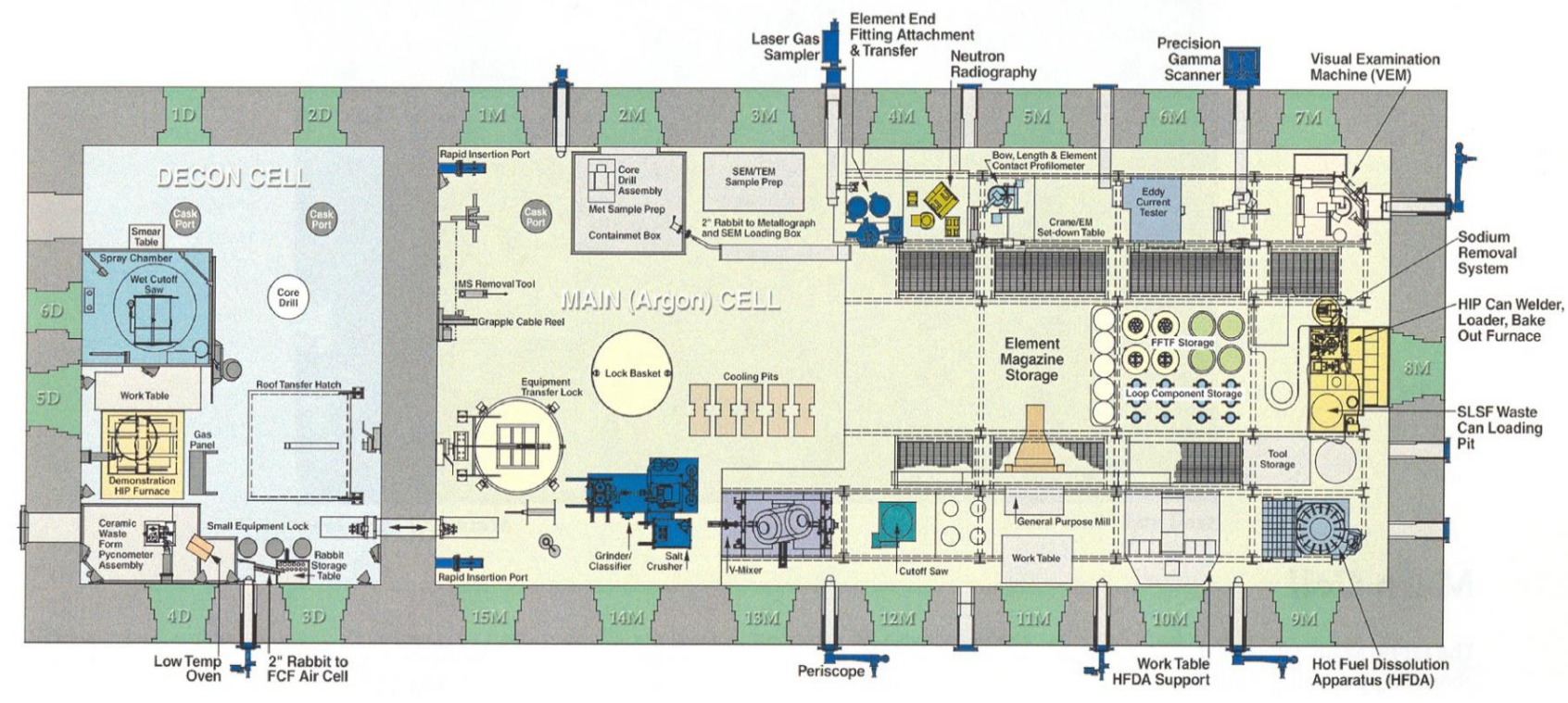




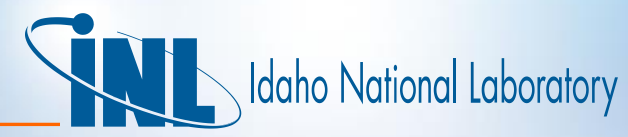

\section{Hot Fuel Examination Facility(HFEF)}

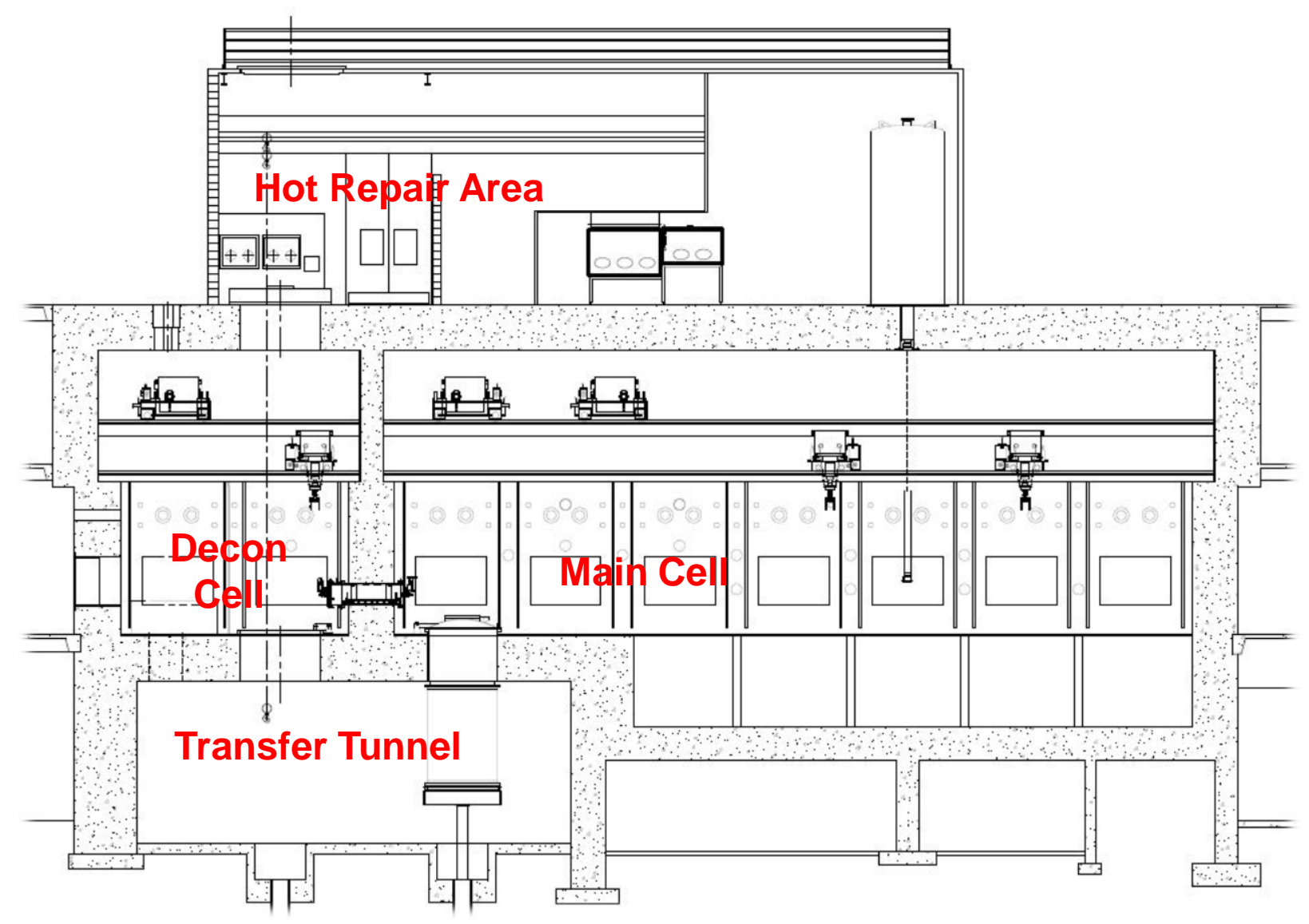




\section{HFEF Main Cell Atmosphere Control}

- Cell Pressure

- Normal Range: -1 to -4 in. w.c.(-250 to $-100 \mathrm{~Pa})$

- Minimum: -22 in w.c. (-5.4 kPa)

- Maximum: +3 in. w.c. $(74 \mathrm{~Pa})$

- Temperature

- Normal Range: $70-100 \operatorname{deg} F(21-37 \operatorname{deg} C)$

- Min $65 \operatorname{deg} F(18 \operatorname{deg} \mathrm{C})$

- Max $105 \operatorname{deg} F(40 \operatorname{deg} \mathrm{C})$

- Oxygen: 25 - 100 ppm

- Moisture: 20 - 100 ppm 


\section{HFEF Main Cell Atmosphere Control (Continued)}

- Main Cell Cooling System

- Circulate and cool the cell gas

- Removes the heat via cooling fluid and refrigeration system

- Controls cell pressure

- HEPA Filtered

- Vent System

- Seal pot (No. 1) prevents back diffusion of air into the cell

- Argon Supply

- Addition of clean argon

- Addition of emergency argon for under pressure protection

- Pressure Relief

- Seal Pot (No. 2) Over and under pressure protection

- Purification System

- Removes moisture and oxygen from the cell atmosphere

- Atmosphere Monitoring 


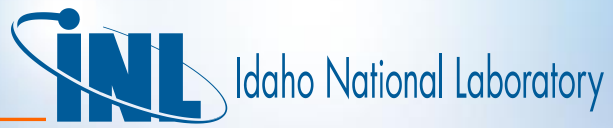

\section{HFEF Main Cell Atmosphere Control (Continued)}

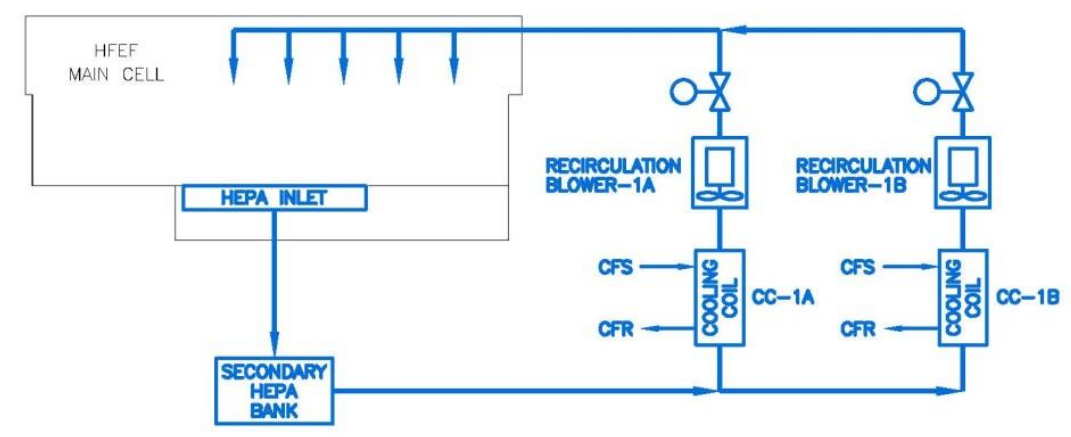




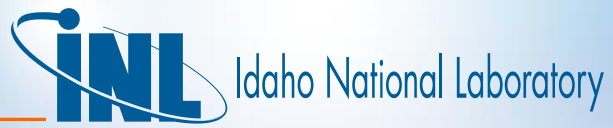

\section{HFEF Main Cell Atmosphere Control (Continued)}

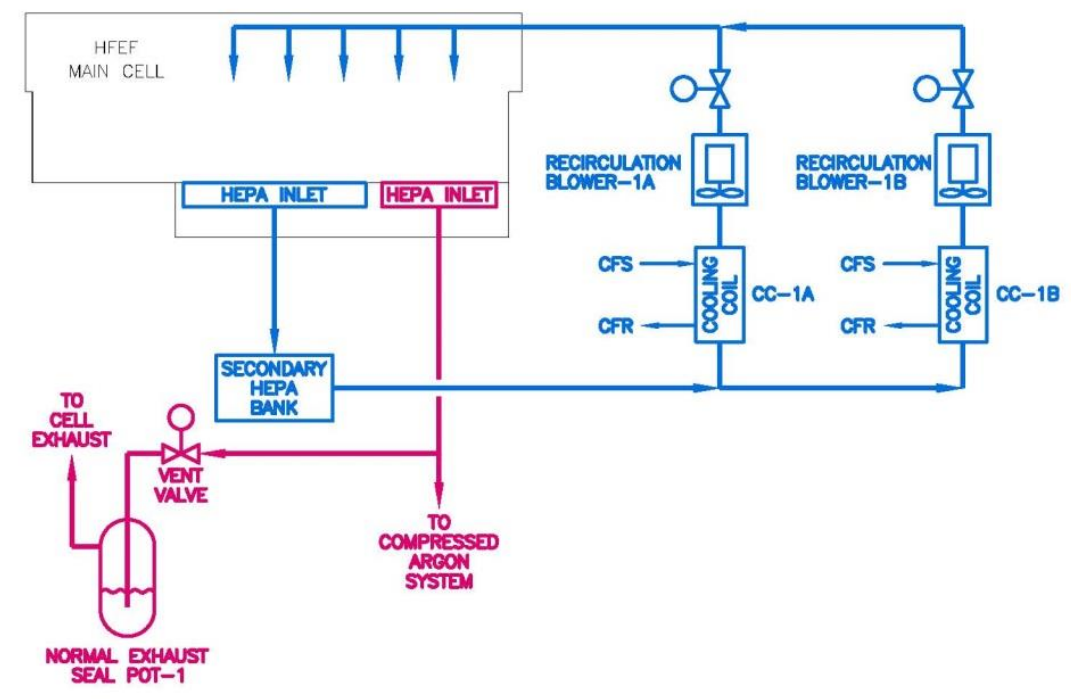




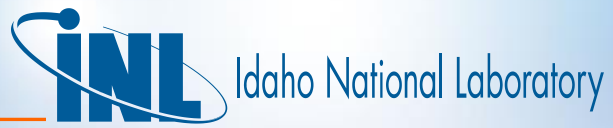

\section{HFEF Main Cell Atmosphere Control (Continued)}

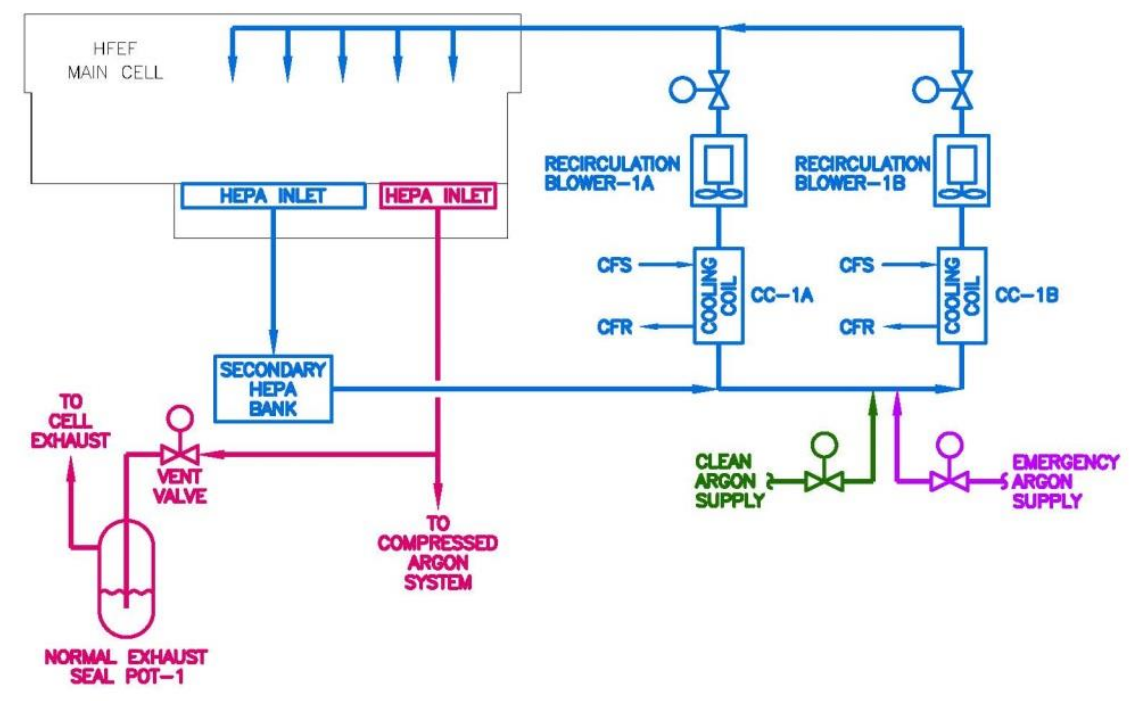




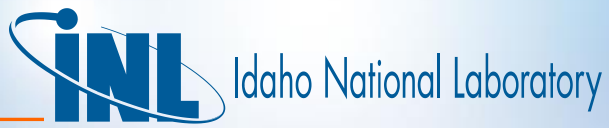

\section{HFEF Main Cell Atmosphere Control (Continued)}

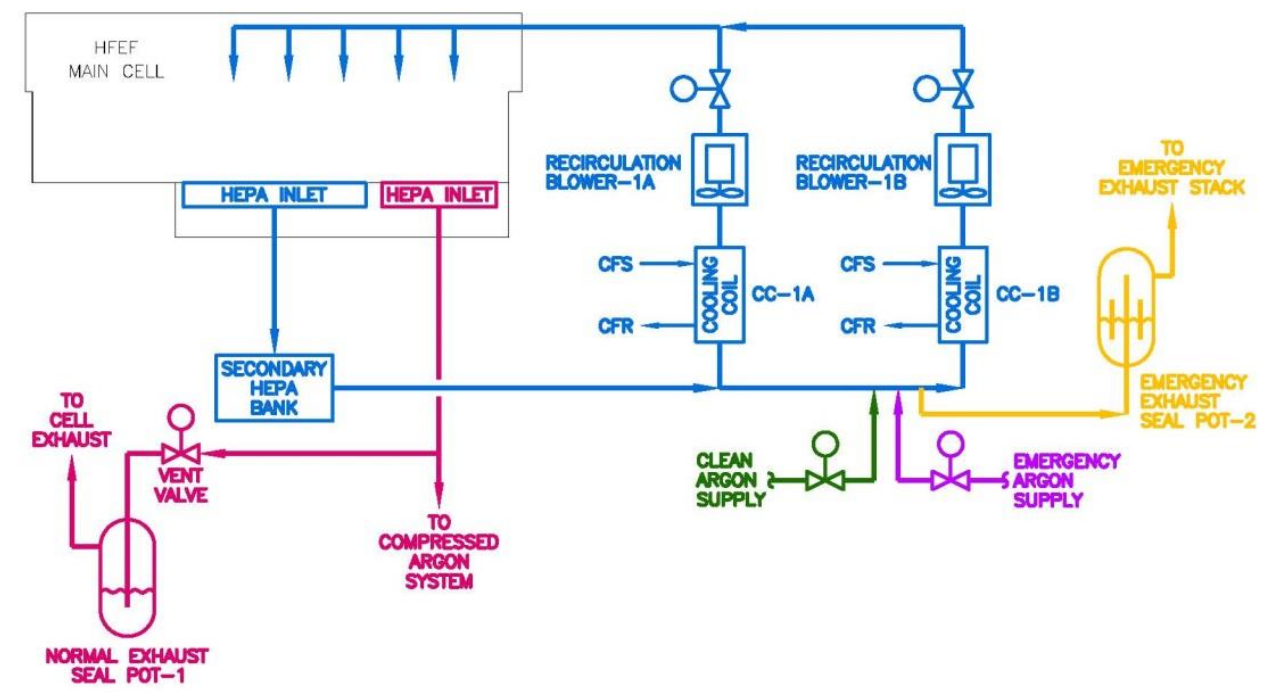




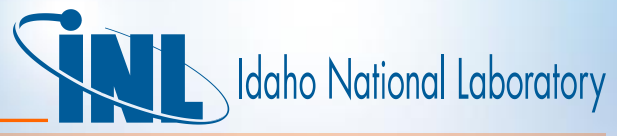

\section{HFEF Main Cell Atmosphere Control (Continued)}

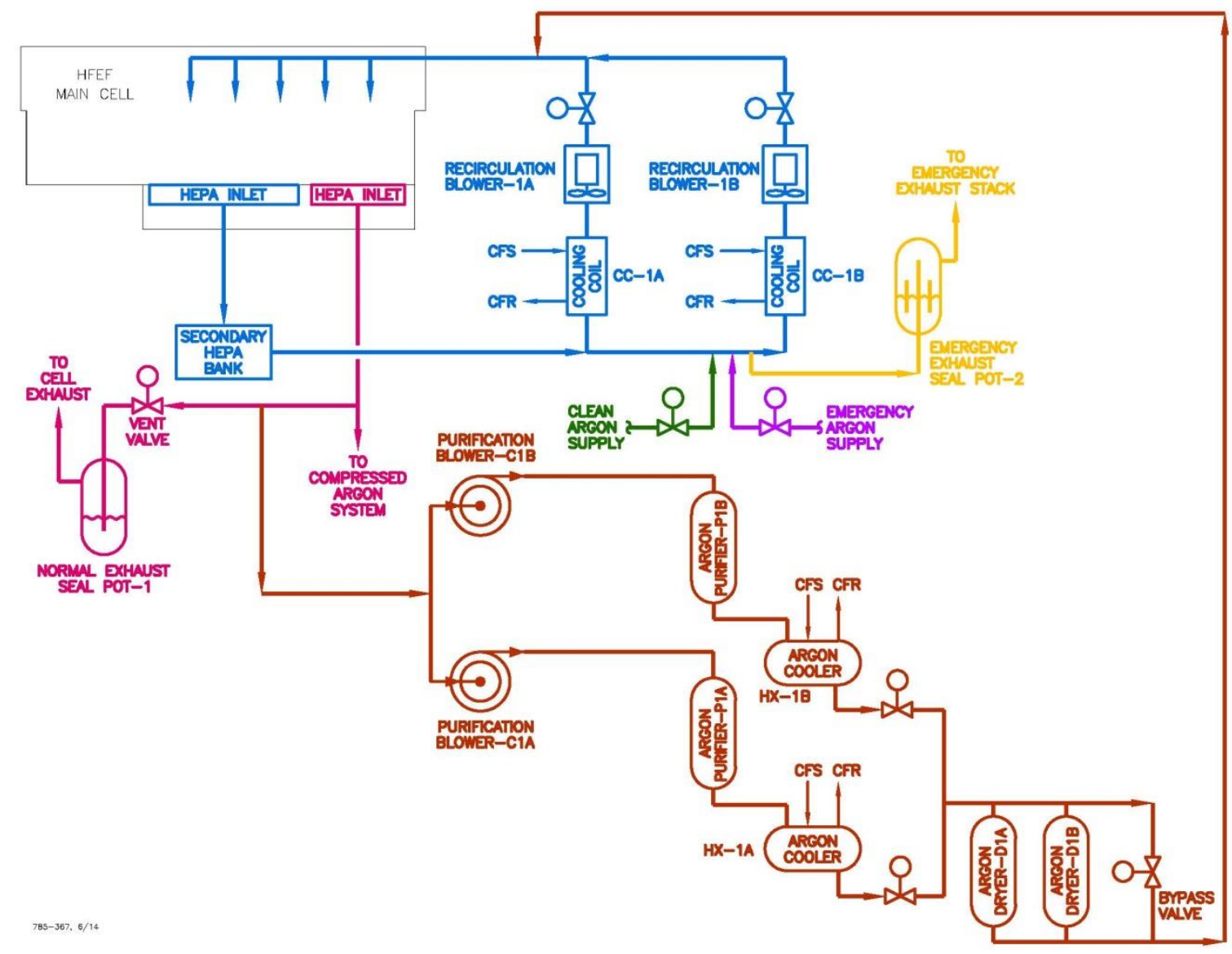




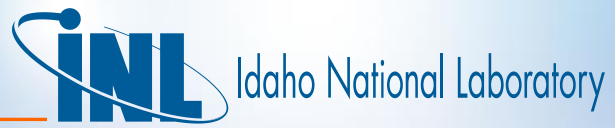

\section{HFEF Main Cell Atmosphere Control (Continued)}

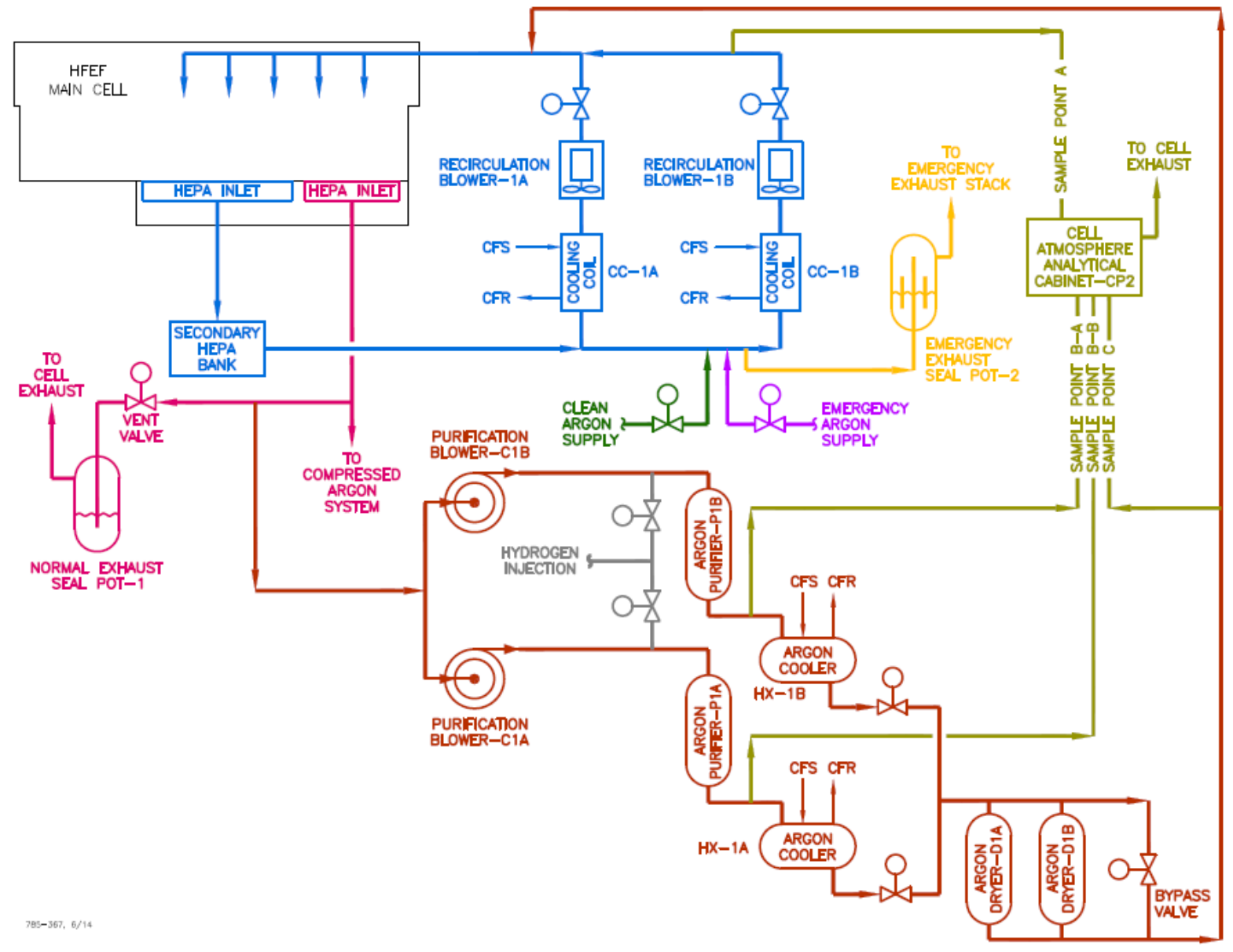




\section{HFEF Main Cell Shield Windows}

- Oil-filled

- Leaded glass shielding windows

- Hinged protective cover plate (in-cell)

- Oil Expansion tank with argon cover gas

- Light Transmittance: 38\% 


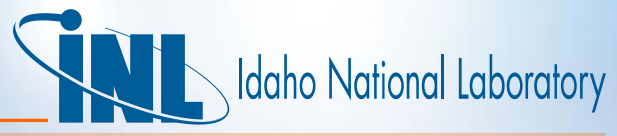

\section{HFEF Main Cell Shield Windows (Continued)}

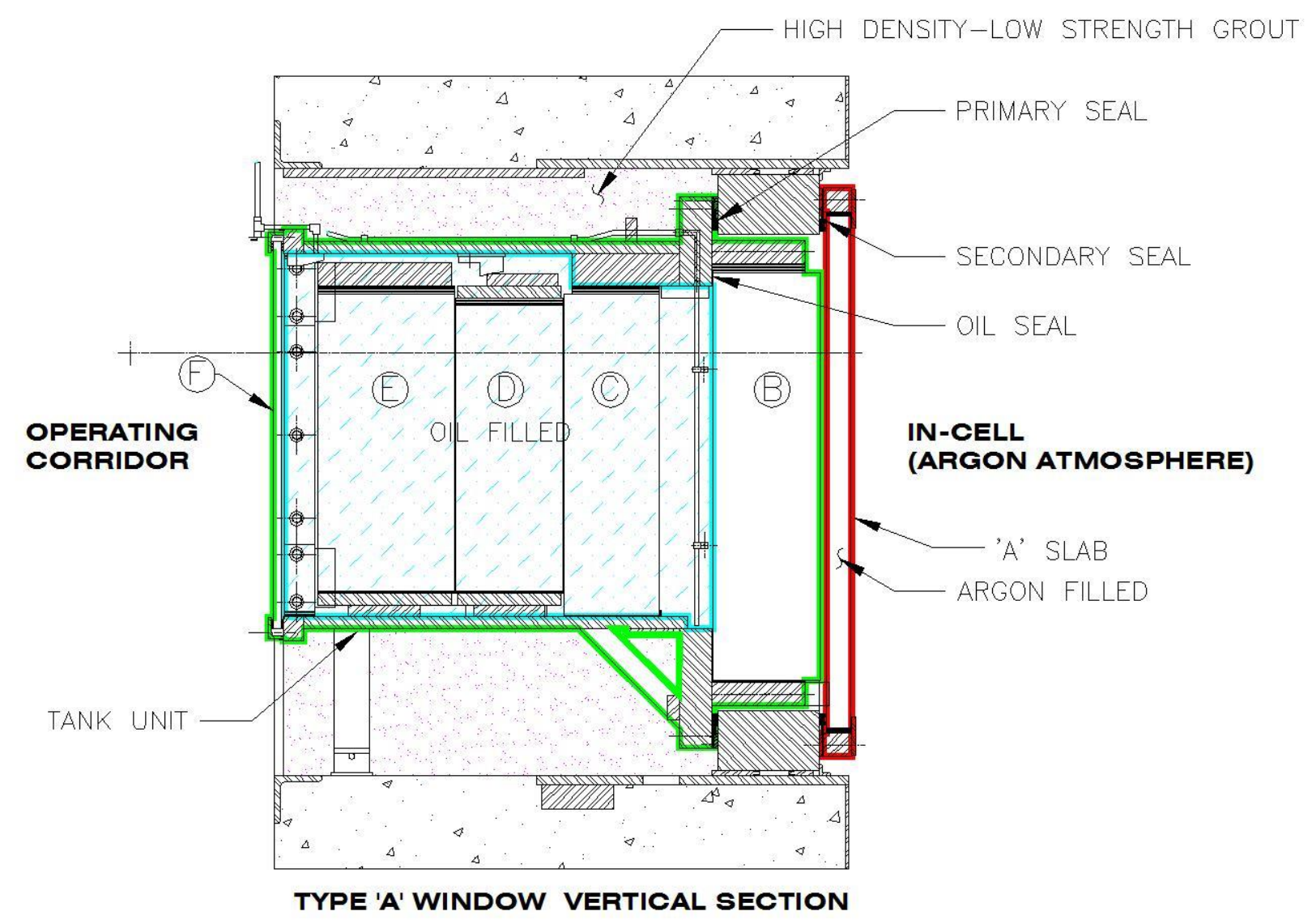




\section{HFEF Main Cell Shield Windows (Continued)}

- The tank assembly contains three heavy glass slabs, labeled C and D (cerium-stabilized), and $\mathrm{E}$. The hot end is sealed with a 9 in. thick slab of cerium stabilized glass (B) and the cold end is sealed with a 20-mm-thick plate of the same type of glass (F) but with no cerium (total glass weight is $6734 \mathrm{lb} / 6734 \mathrm{~kg}$ ). The glass schedule is as follows:

\begin{tabular}{|l|l|l|l|}
\hline Slab & Density & Thickness & $\begin{array}{l}\text { Composition } \\
\text { Comments }\end{array}$ \\
\hline A & 2.53 & $5.1 \mathrm{~cm}(2$ in. $)$ & Cerium-stabilized \\
\hline B & 2.53 & $22.9 \mathrm{~cm}(9$ in. $)$ & Cerium-stabilized \\
\hline C & 3.23 & $20.3 \mathrm{~cm}(8$ in. $)$ & Cerium-stabilized \\
\hline D & 3.23 & $22.9 \mathrm{~cm}(9$ in. $)$ & Cerium-stabilized \\
\hline E & 5.20 & $29.2 \mathrm{~cm}(11.5 \mathrm{in})$. & \\
F & 2.53 & $1.9 \mathrm{~cm}(0.75$ in. $)$ & \\
\hline
\end{tabular}




\section{Material Handling System Overview}

- Maximum Overall Equipment Handling Envelope (not including casks)

- Capacity - 5 Ton $(4,540 \mathrm{~kg})$

- Max Height - 12 ft. 10 in. (3.91 m)

- Max Diameter - $6 \mathrm{ft}$. (1.83 m)

- In-Cell Overhead Handling (Three Levels)

- Repair Hoist (Maintenance Use Only)

- Cranes

- Electro - Mechanical Manipulator (EM or EMM)

- Through the Wall Manipulators

- Transfer Systems

- Large Lock

- Small Lock

- Rapid Insertion Port

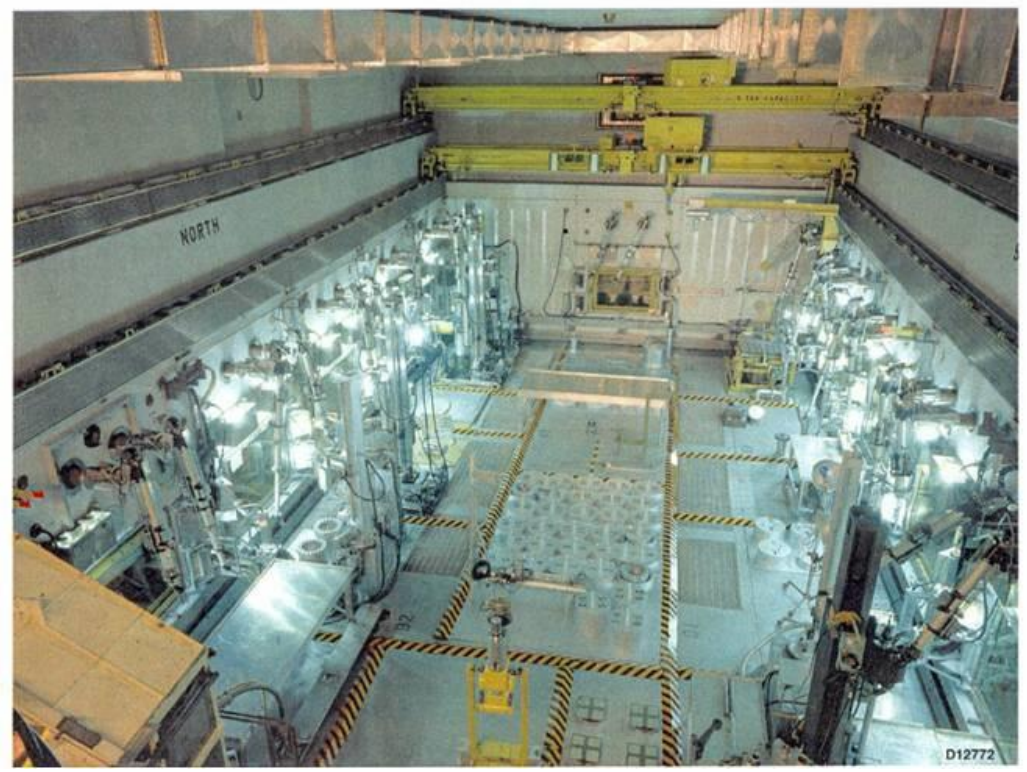




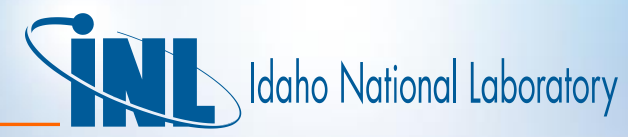

\section{Hot Fuel Examination Facility(HFEF) Overhead Handling}

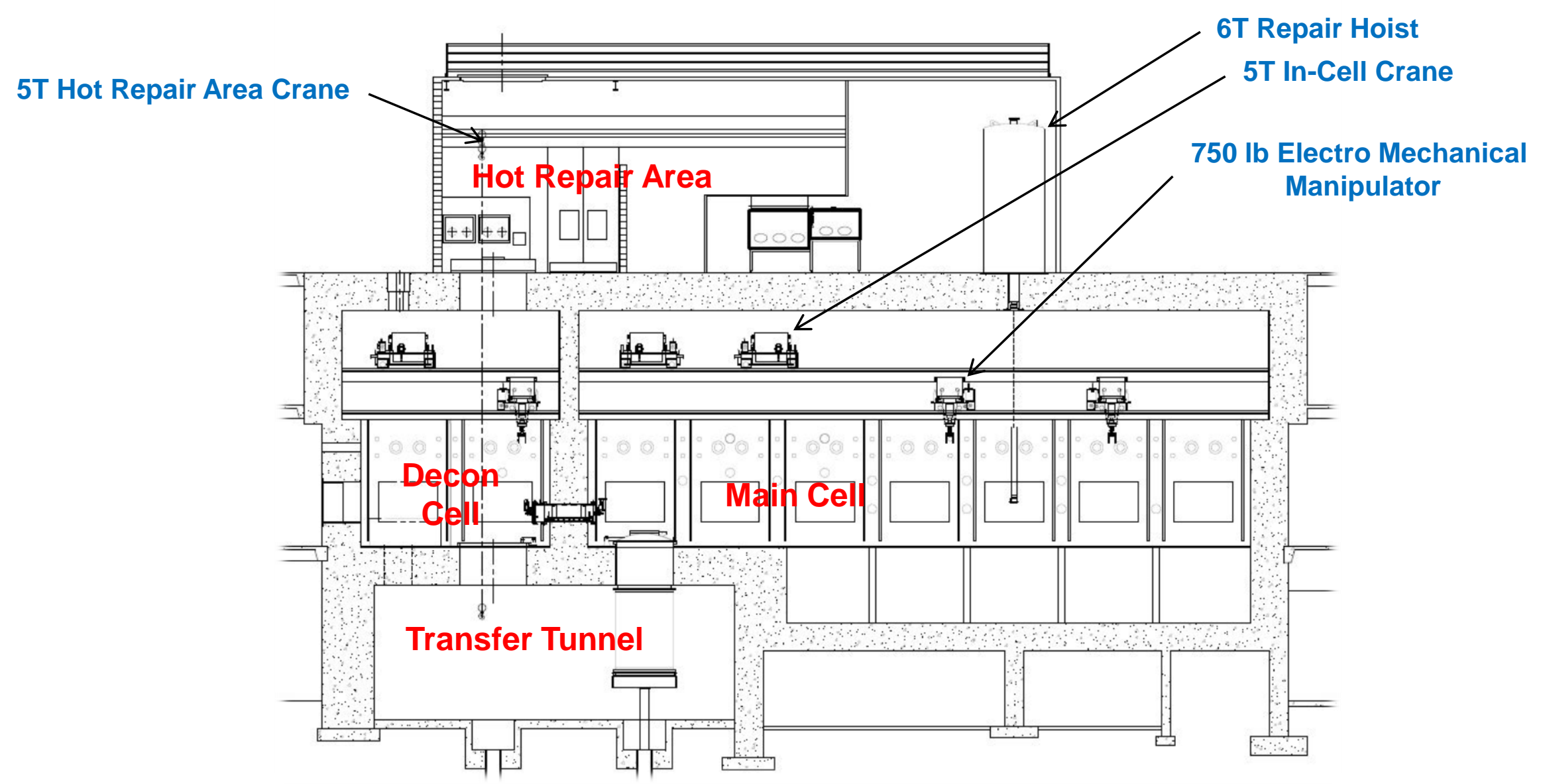




\section{Hot Fuel Examination Facility(HFEF) Overhead Handling (Continued)}

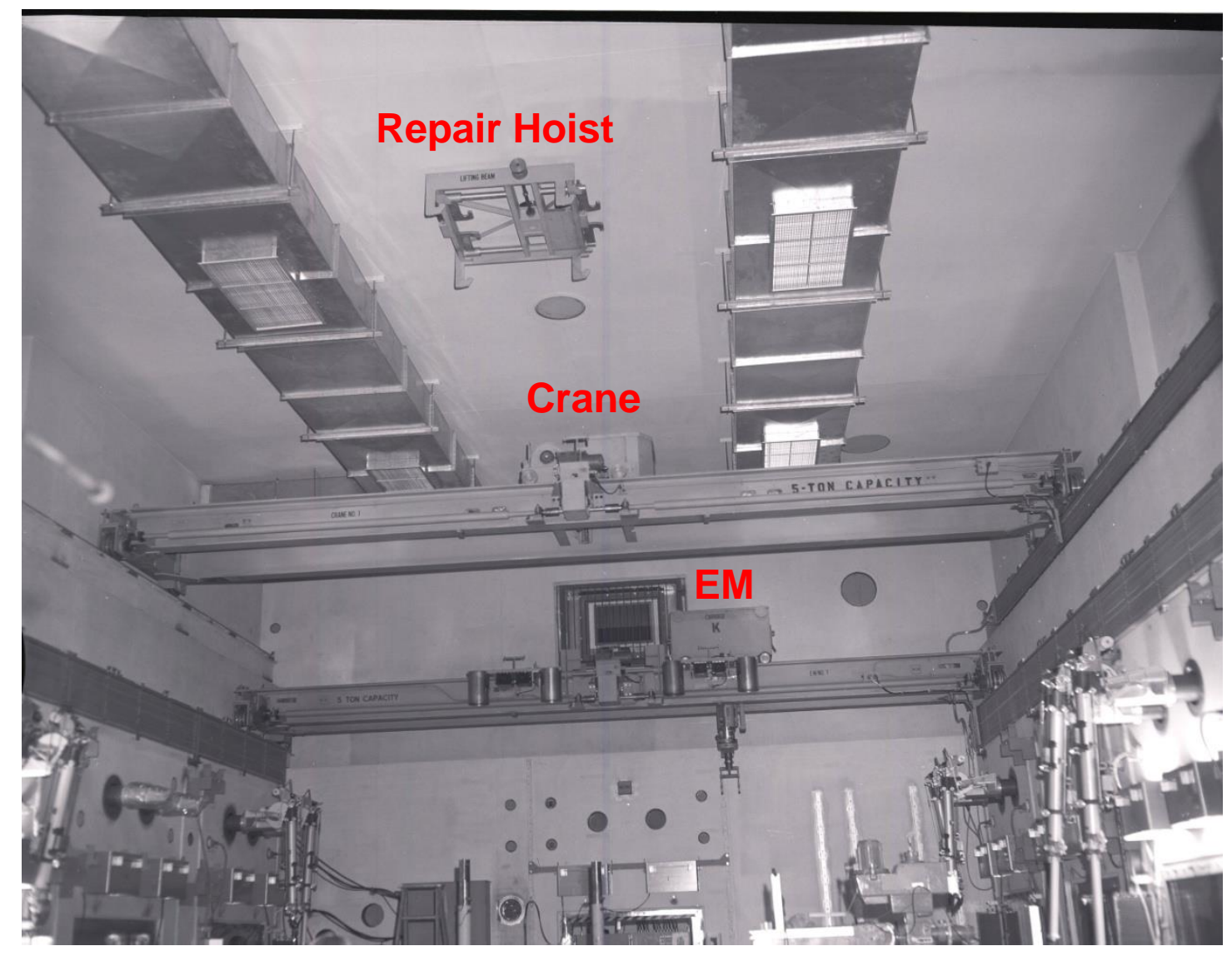




\section{Hot Fuel Examination Facility(HFEF)}

\section{Overhead Handling (Continued)}

- Repair Hoist (Maintenance Use Only)

- For removal of EM carriages, crane trolleys, bridge drive modules, bridge removal, and supports buss bar replacement

- Capacity - 6 T (required for bridge removal)

- Rotation for removing bridges and swapping carraiges/trolleys between bridges.

- Rigid tube (10ft/3.05 m)) for rigid positioning for placing components on bridges. Hollow tube is only in affect at the bridge level and above.

- Isolable and shielded from the main cell for entry into the repair hoist confinement.

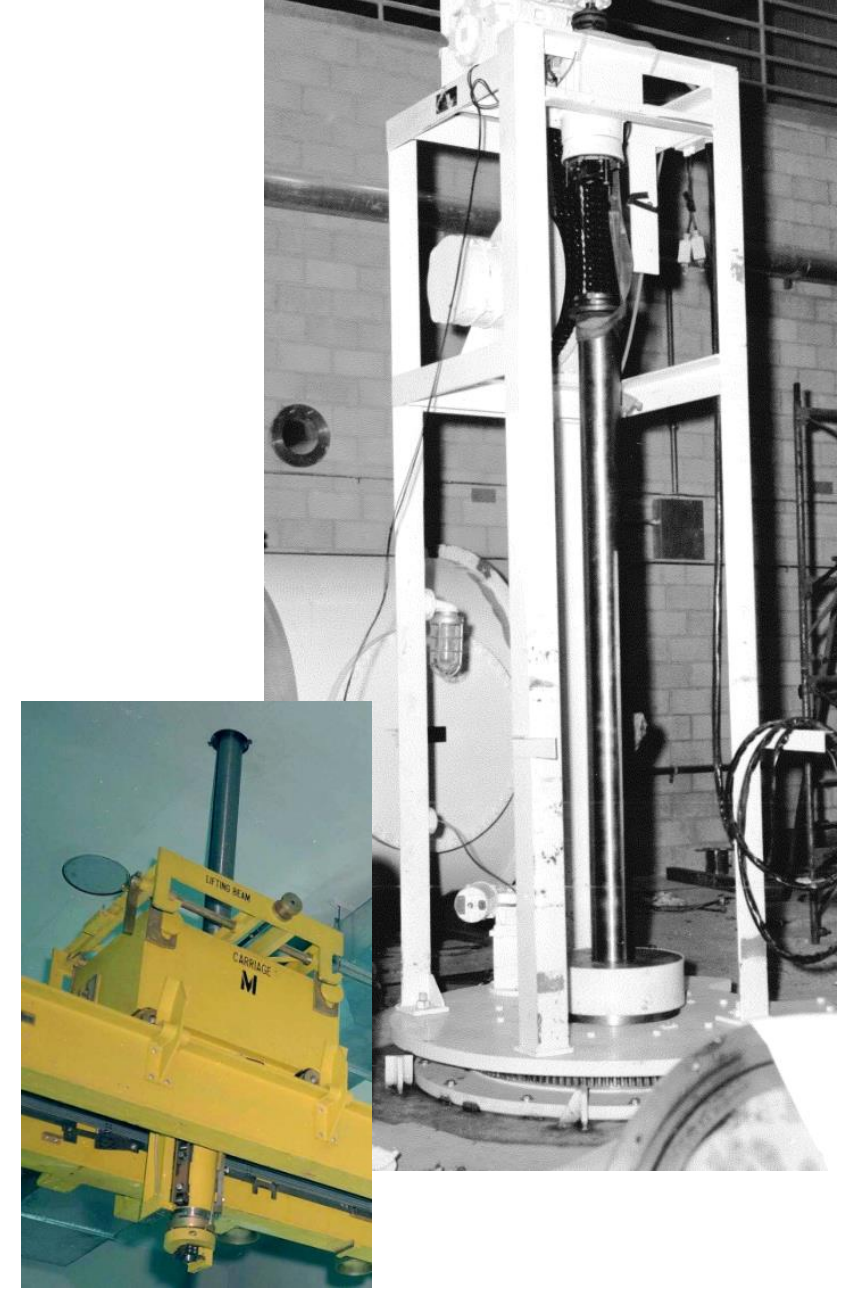




\section{Hot Fuel Examination Facility(HFEF) Overhead Handling (Continued)}

- In-Cell Crane

- General lifting and handling

- 5 T Capacity

- Remotely removable components

- Crane Trolley

- Bridge Drive Module

- Bridge

- Wall Buss Bars

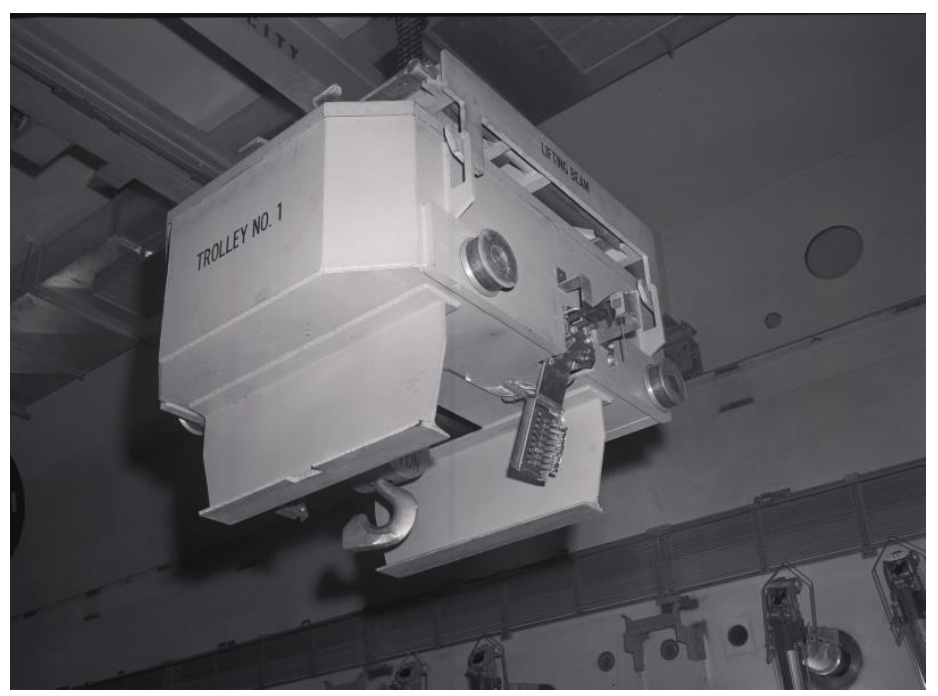




\section{Hot Fuel Examination Facility(HFEF) Overhead Handling (Continued)}

- Electro-Mechanical Manipulator (EM)

- Majority of in-cell lifting and handling

- Lift $750 \mathrm{lbs}(340 \mathrm{~kg})$

- Rotate $100 \mathrm{ft}-\mathrm{lbs}\left(135 \mathrm{~N}^{*} \mathrm{~m}\right)$

- End Effectors

- Dual Grip

- Single Grip

- Parallel Jaws

- Off-Center Load

- Articulated Arm (PaR 3000) (not currently used)

- Bridge Cell Lighting
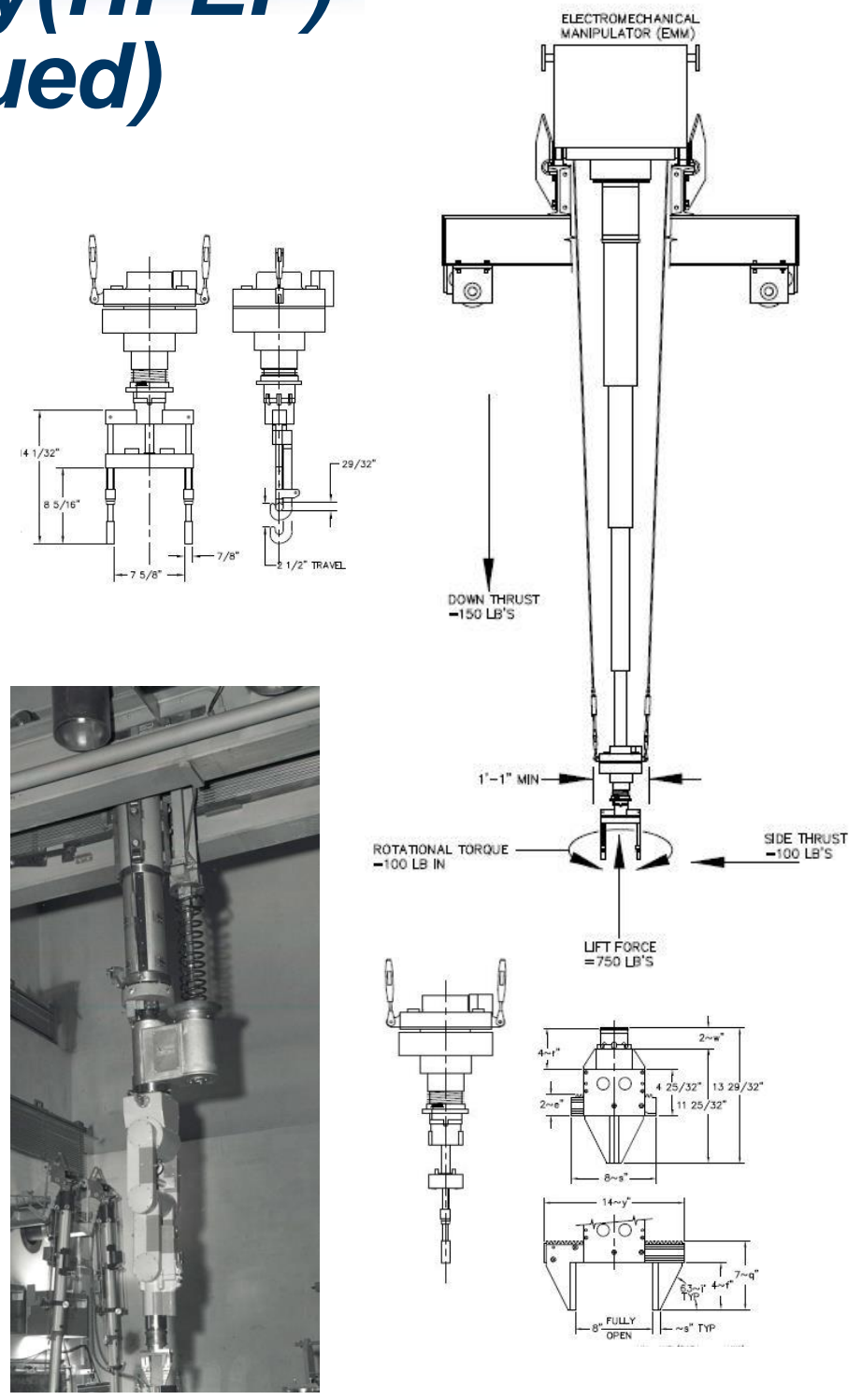


\section{Hot Fuel Examination Facility(HFEF) Overhead Handling (Continued)}

- Minimum Configuration (Main Cell)

- One Crane with access to the transfer lock

- OR, one EM for supporting repair hoist operations

If one of the conditions is met, only handling operations to return the cell to full operations is permitted.

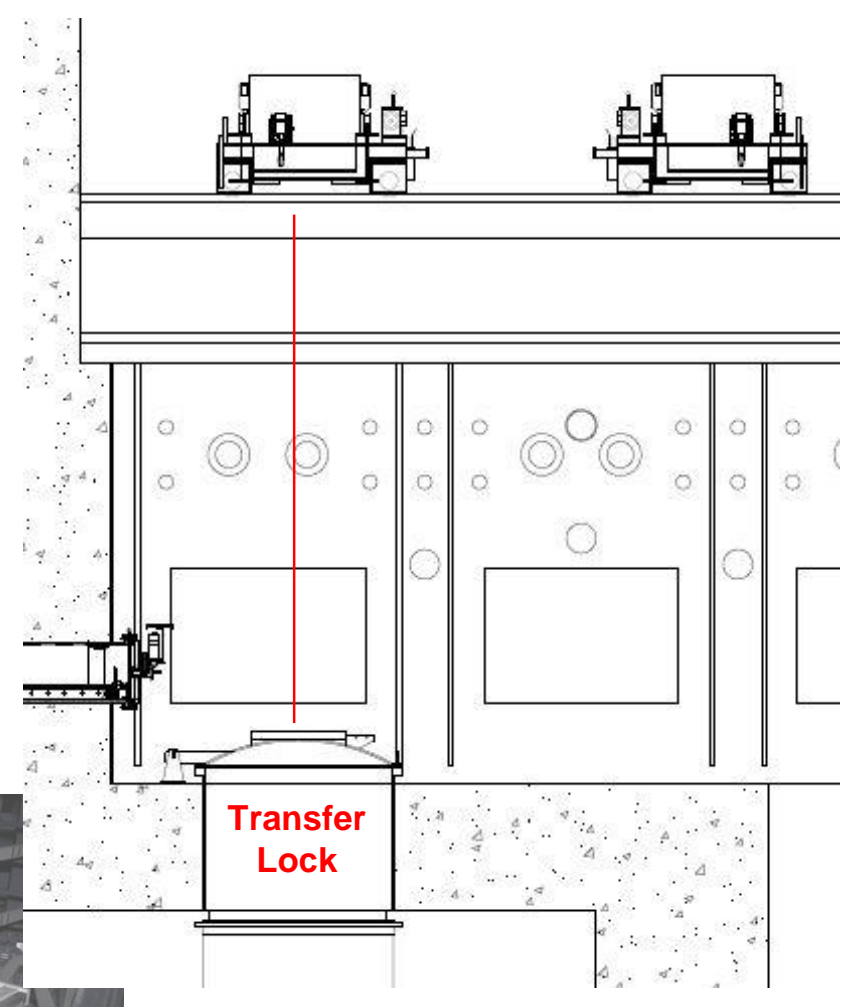




\section{Hot Fuel Examination Facility(HFEF)}

Thru Wall Manipulators

- One piece manipulator is desirable due to reduced cost, simplicity, increased dexterity. In-cell boot for contamination control lowers dexterity.

- Three piece manipulator (master arm, seal tube, slave arm) is required for negative inert atmospheres.

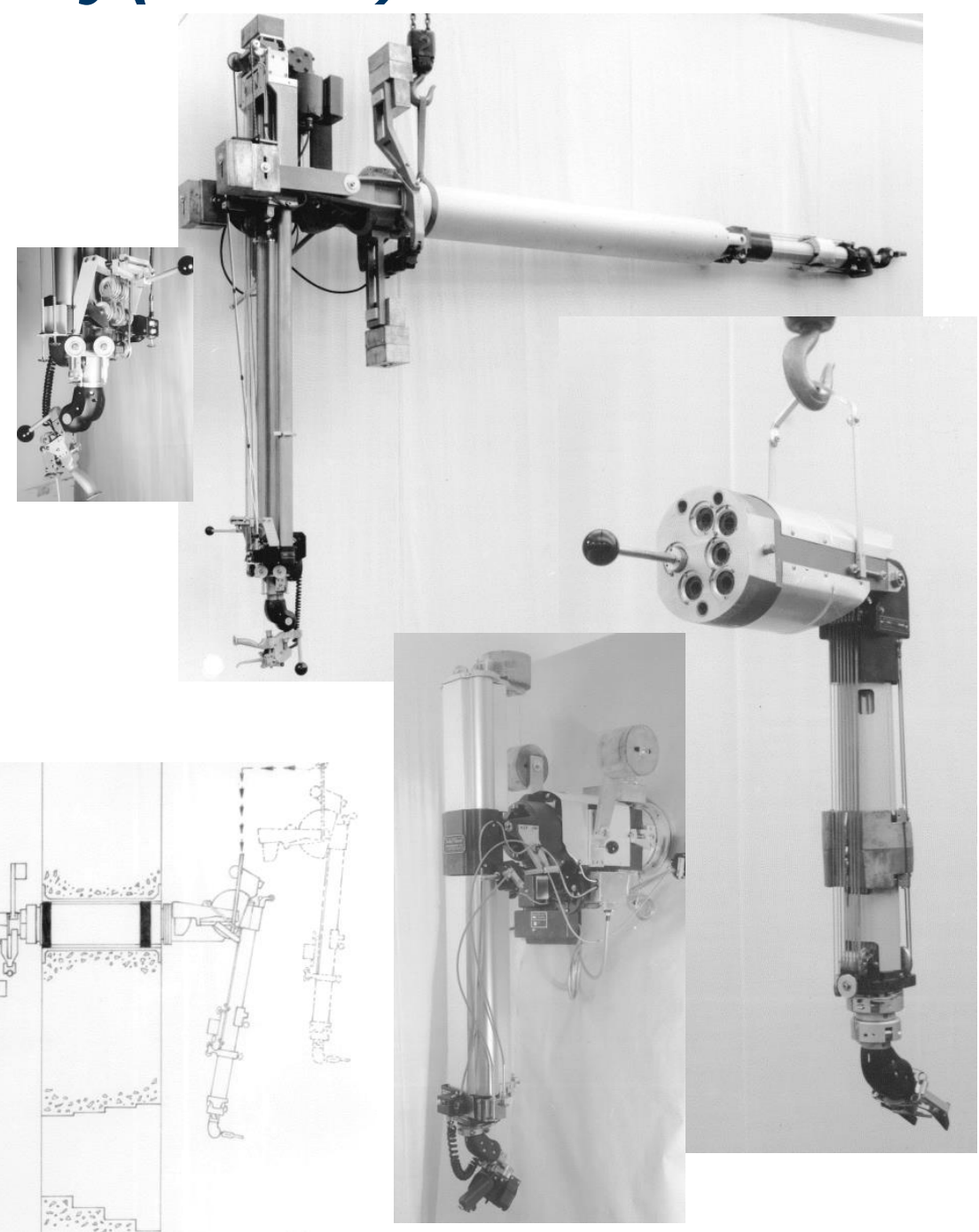




\section{Hot Fuel Examination Facility(HFEF) Transfer Systems}

- Large Lock - for the transfer of large objects (max transfer envelope) between the decon cell and the main cell while maintaining the cell atmosphere.

- Small Lock - for the transfer of small objects (max transfer envelope) between the decon cell and the main cell while maintaining the cell atmosphere.

- Rapid Insertion Port (RIP) - for the transfer of small objects (Approximately 5 in. dia $\times 18$ in long/12.7 $\mathrm{cm} \times 45.7 \mathrm{~cm}$ ) directly into the main or decon cells while maintaining the cell atmosphere.
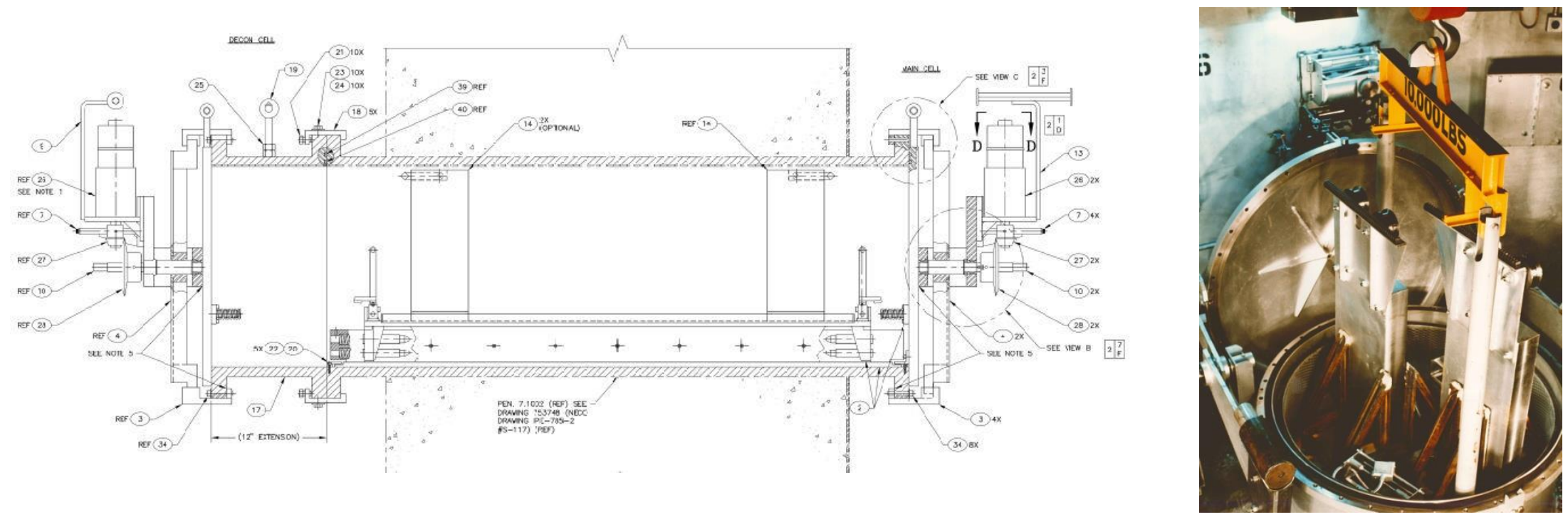


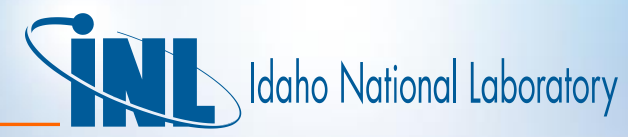

\section{Hot Fuel Examination Facility(HFEF) Transfer Svstems (Continued)}

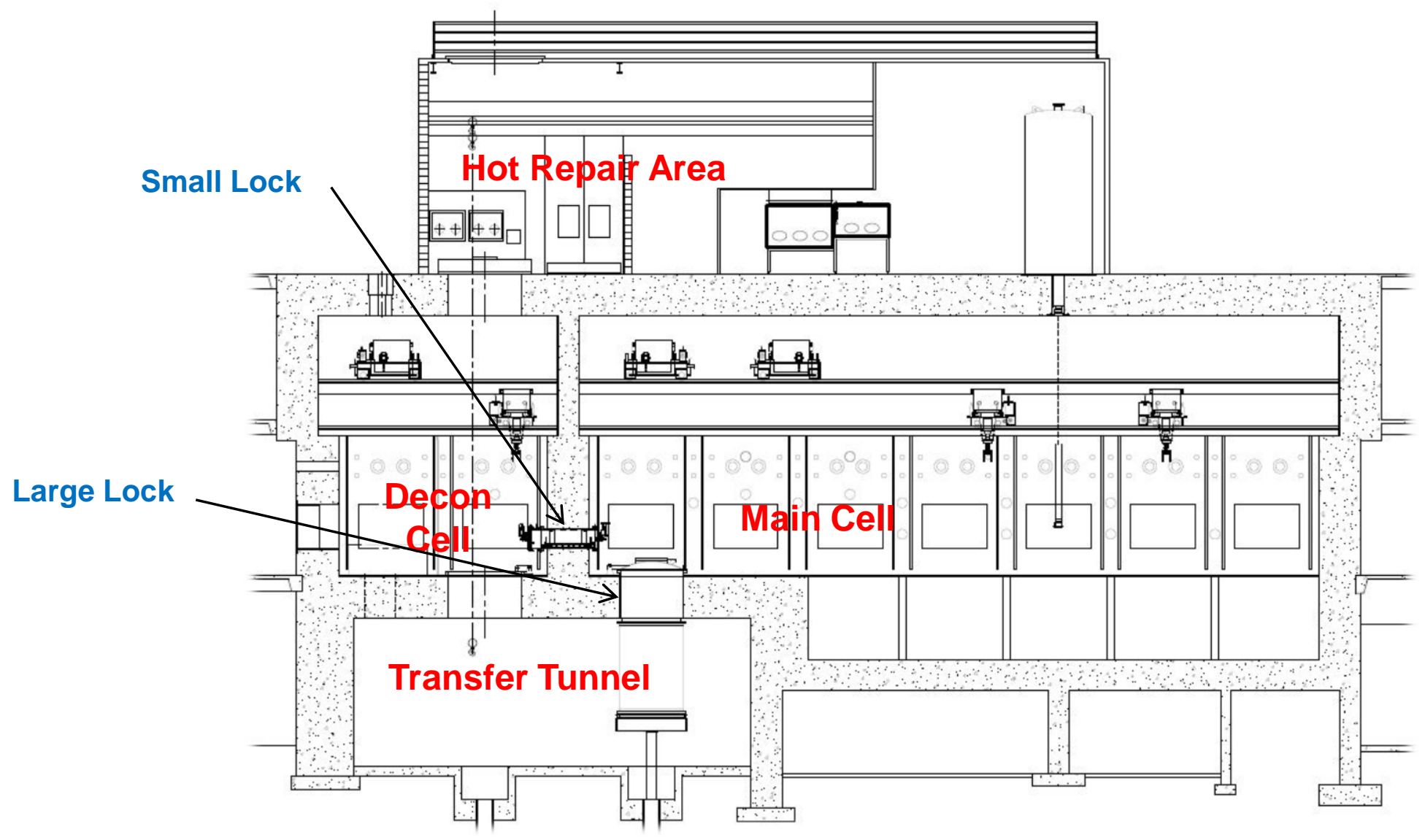




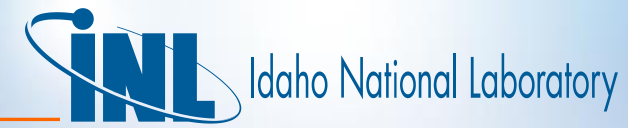

\section{Hot Fuel Examination Facility(HFEF) Cask Transfer Systems}

- Used for vertical transfers of cask payloads into and out of the cells

- Cask Tunnel Penetrations

- Two penetrations in the Decon Cell

- One penetration in the Main Cell

- Cask Cart - 30 Ton Capacity
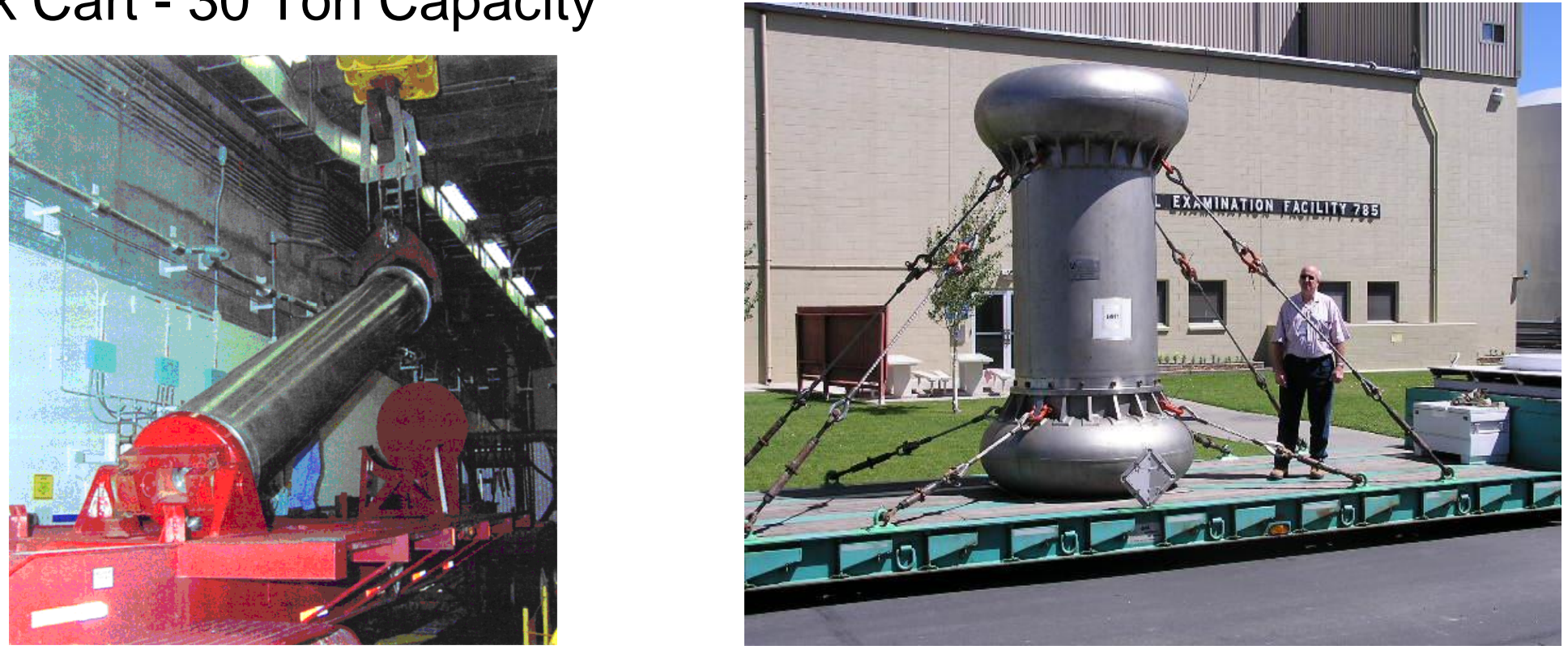


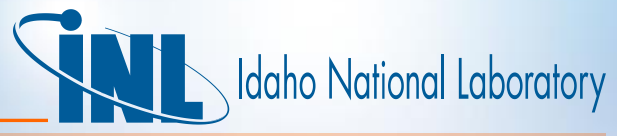

\section{Hot Fuel Examination Facility(HFEF) Cask Transfer Systems (Continued)}

- Cask Transfer to/from truck.

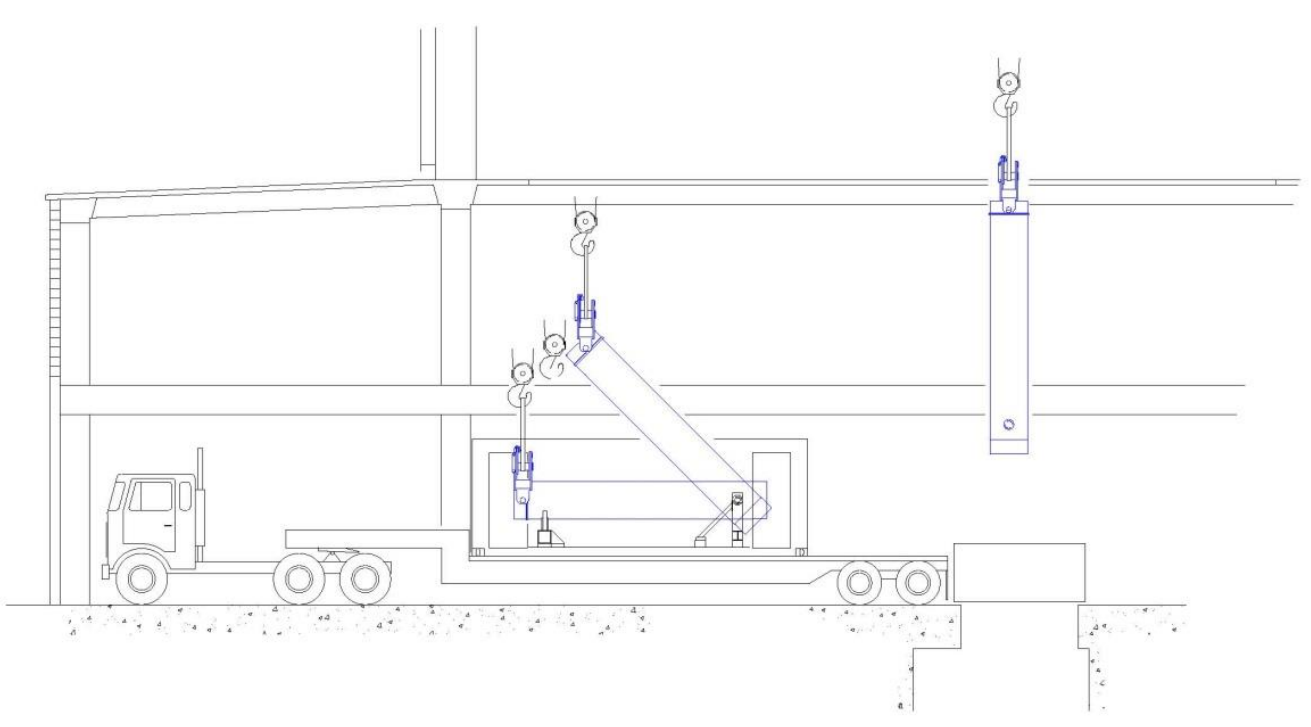




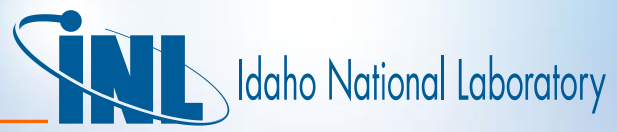

\section{Hot Fuel Examination Facility(HFEF) Cask Transfer Systems (Continued)}

- Cask Tunnel Transfer
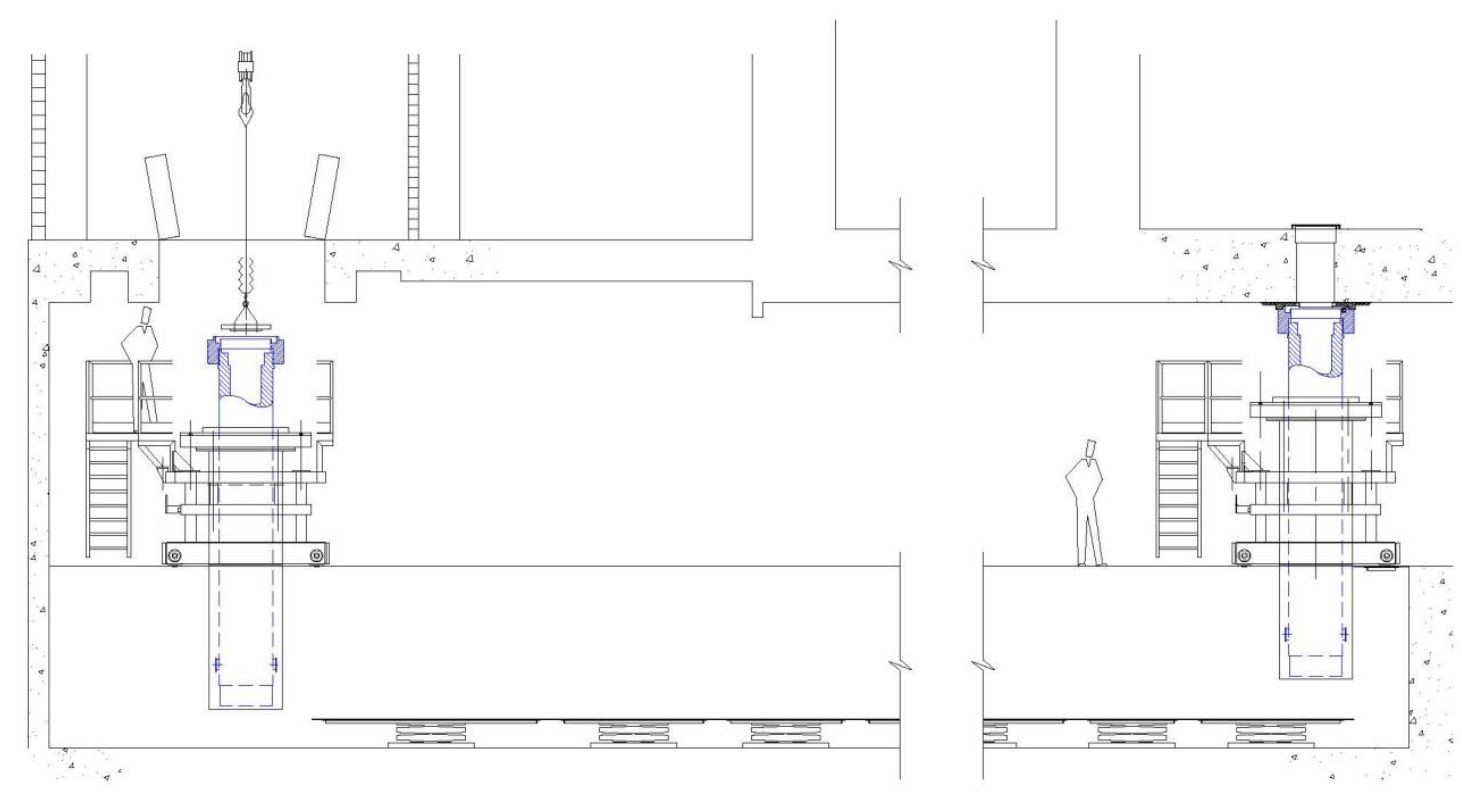


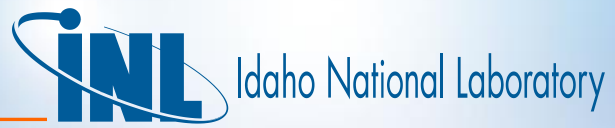

\section{Hot Fuel Examination Facility(HFEF) Cask Transfer Systems (Continued)}

- Cask Bagging Operations

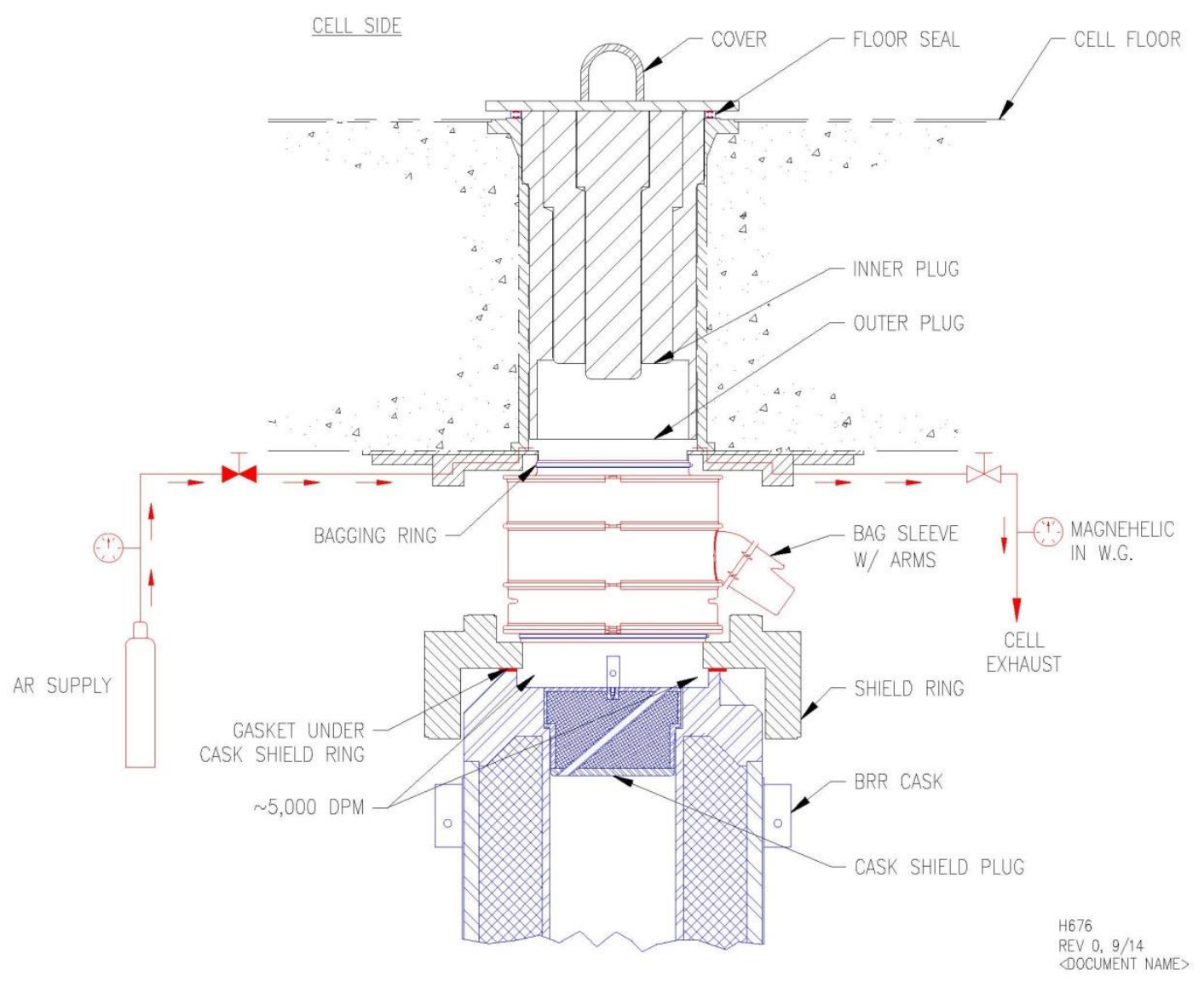


Hot Fuel Examination Facility(HFEF) Cask Transfer Systems (Continued)

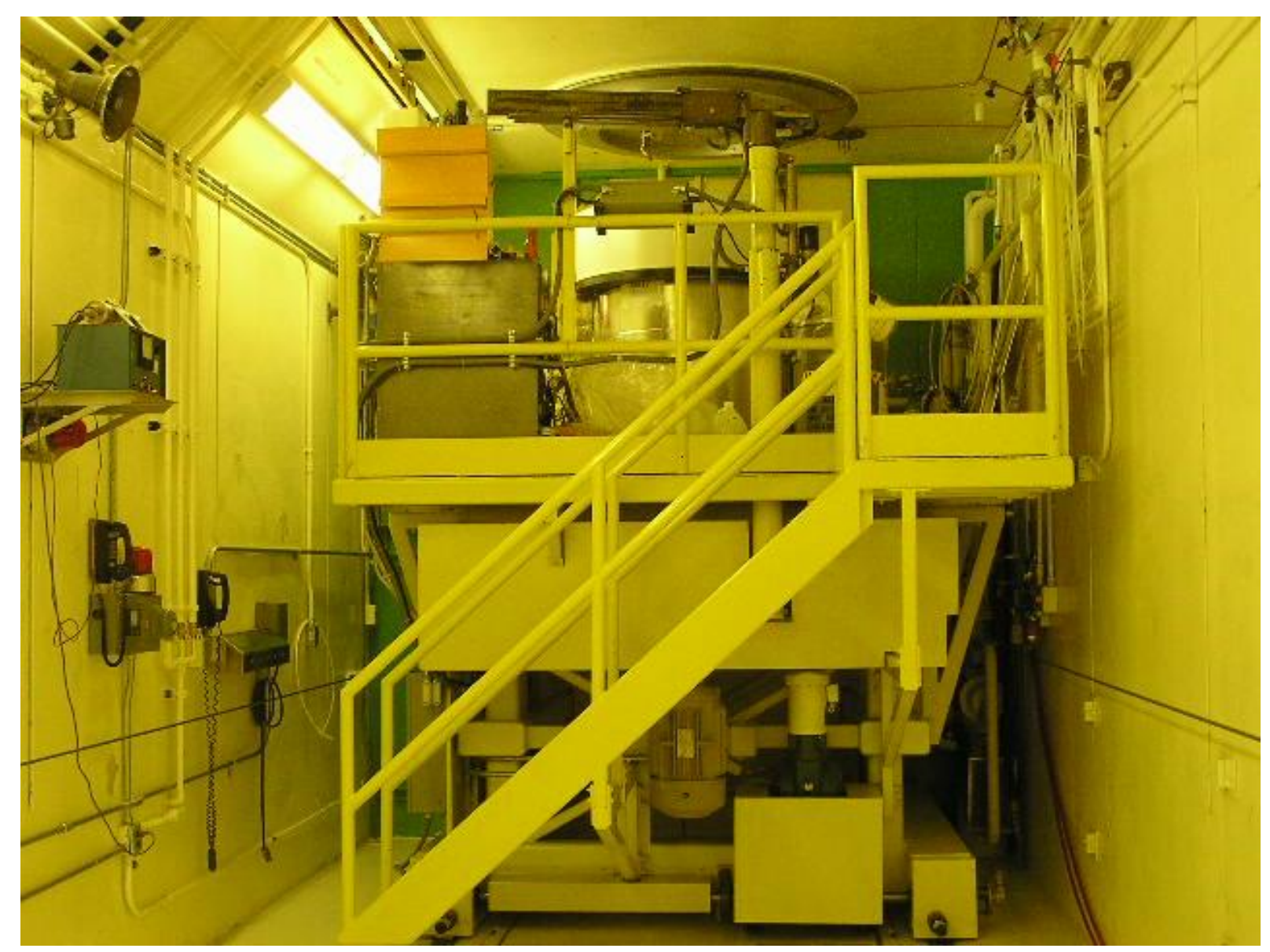




\section{Overhead Handling System Design Features}

- Modular major component design. Frequent major component mechanical and electrical connections integrated into a single operation installation and removal. Major components are normally removed from the cell and transferred to the HRA for contact maintenance.

- Crane trolley or EM carriage (Interchangeable between like bridges)

- Bridge drive module (BDM) for crane bridge and EM bridge (Interchangeable between all bridges)

- EM Bridge Lighting.

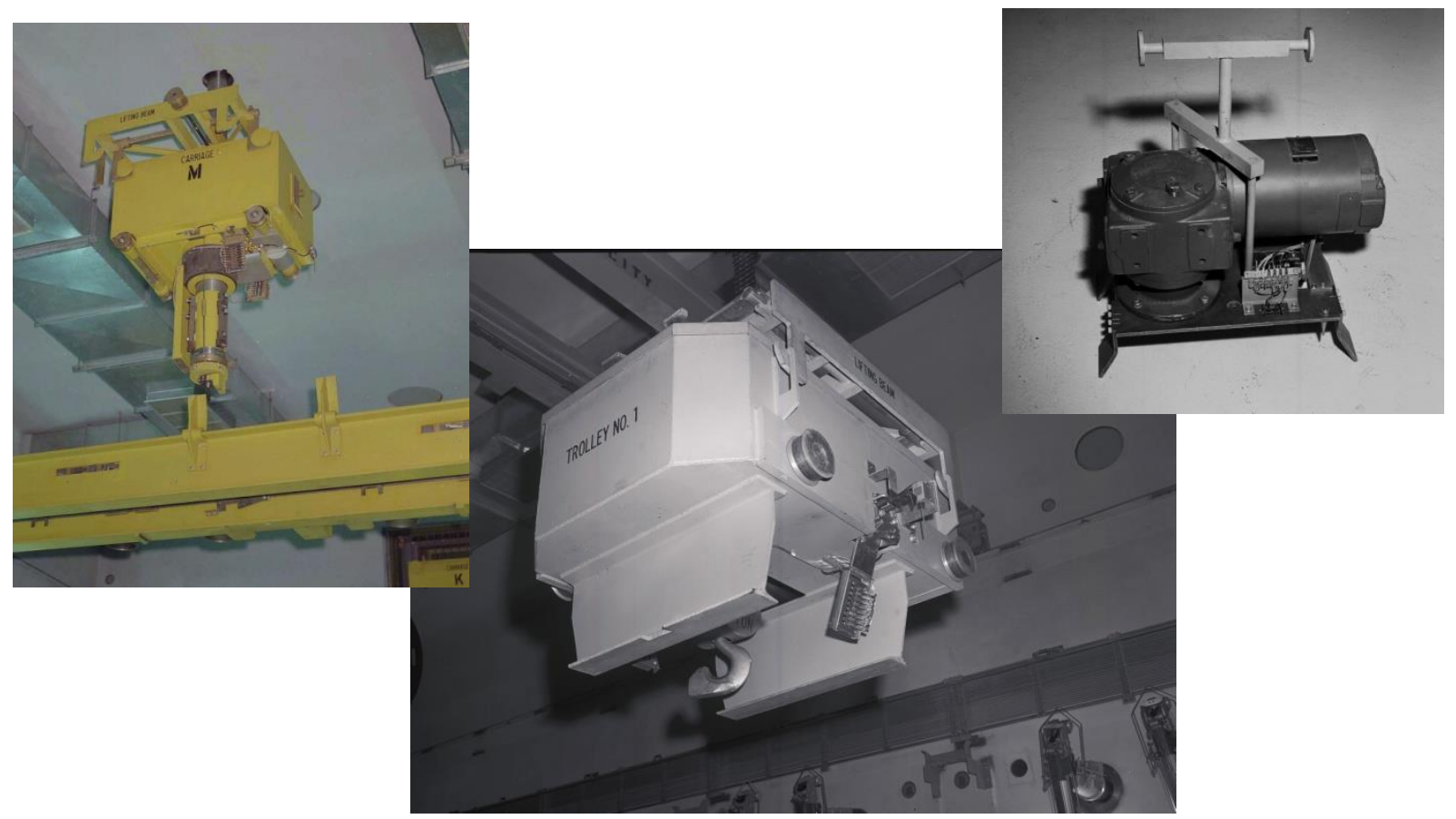




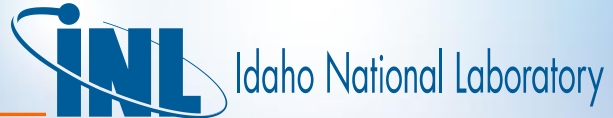

\section{Overhead Handling System Design Features (Continued)}

- Modular component design for motor assemblies within the crane trolley and EM carriage.

- The design allows for remote motor assembly replacement (not practiced).

- Improves access to components and lowers dose associated with repairs.
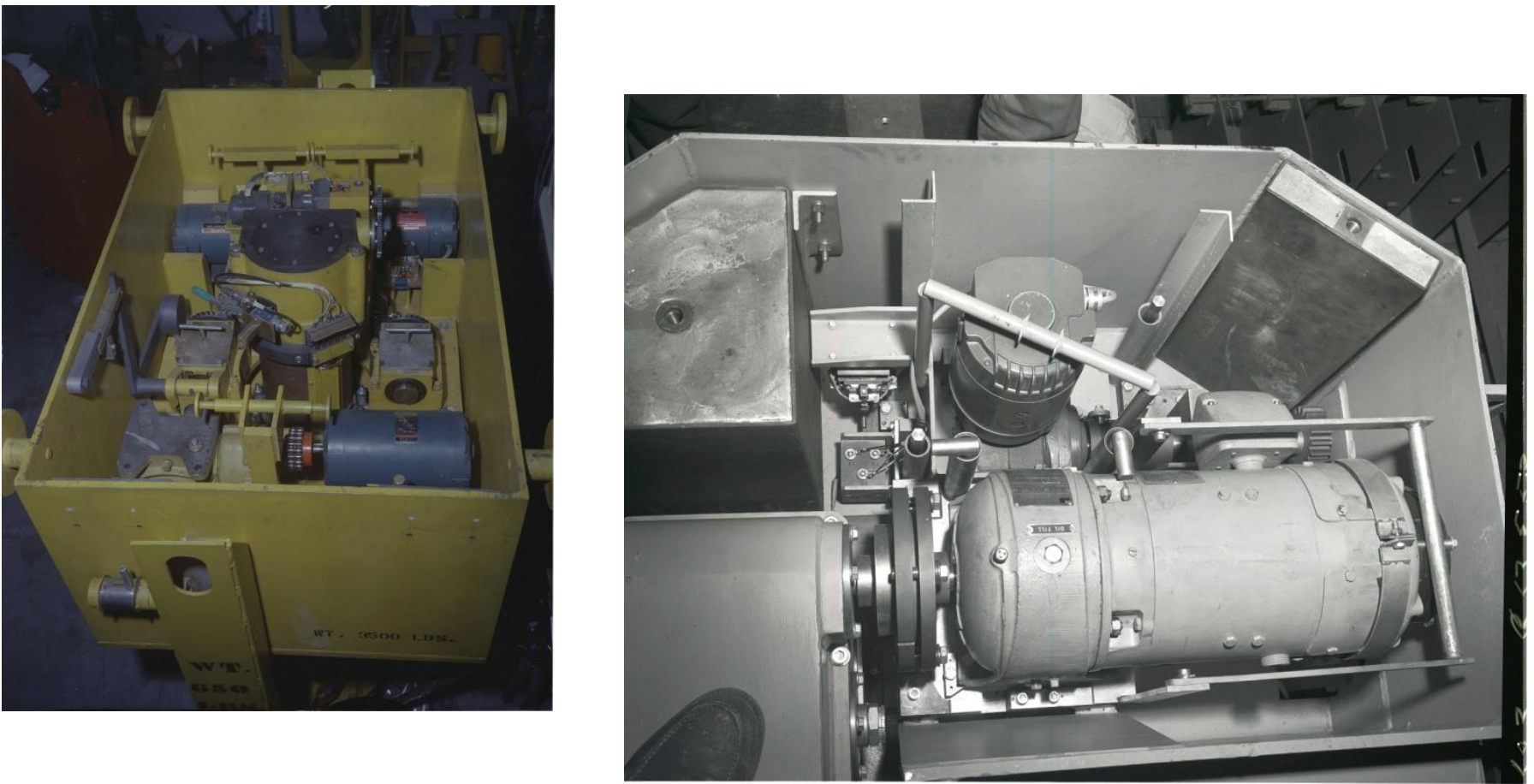


\section{Overhead Handling System Design Features (Continued)}

- Bridge Removal

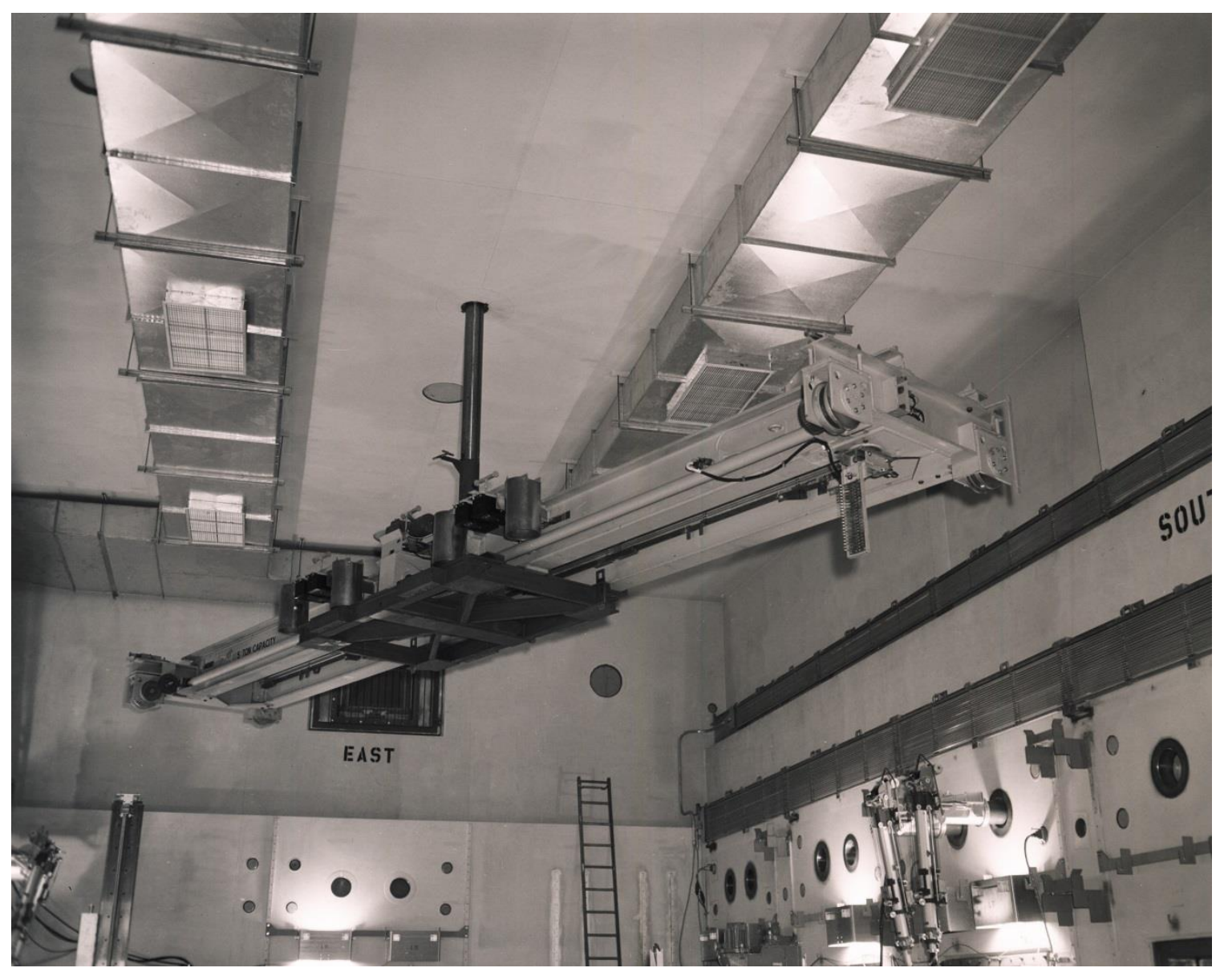




\section{Overhead Handling System Design Features (Continued)}

- Crane and EM Bridge Removal Capability(Main Cell Only)

- Requires bridge lifting beam and stands for supporting the bridge.

- Requires a large area for crane bridge trolley/carriage and staging area.

- Modular design for remote removal of the following:

- Wheel Modules

- Drive Shafts

- Buss Bars

- Brush Pickup Assembly

- Bridge Drive Gearbox

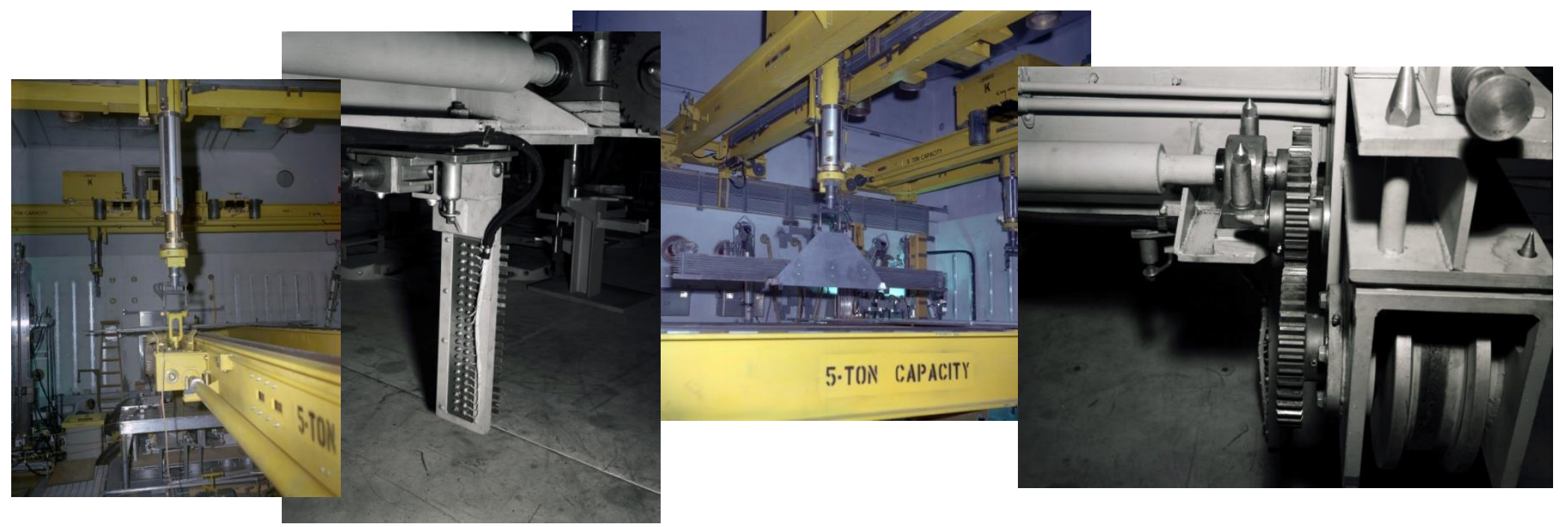




\section{Overhead Handling System Design Features (Continued)}

- Wall Buss Bar Replacement Capability

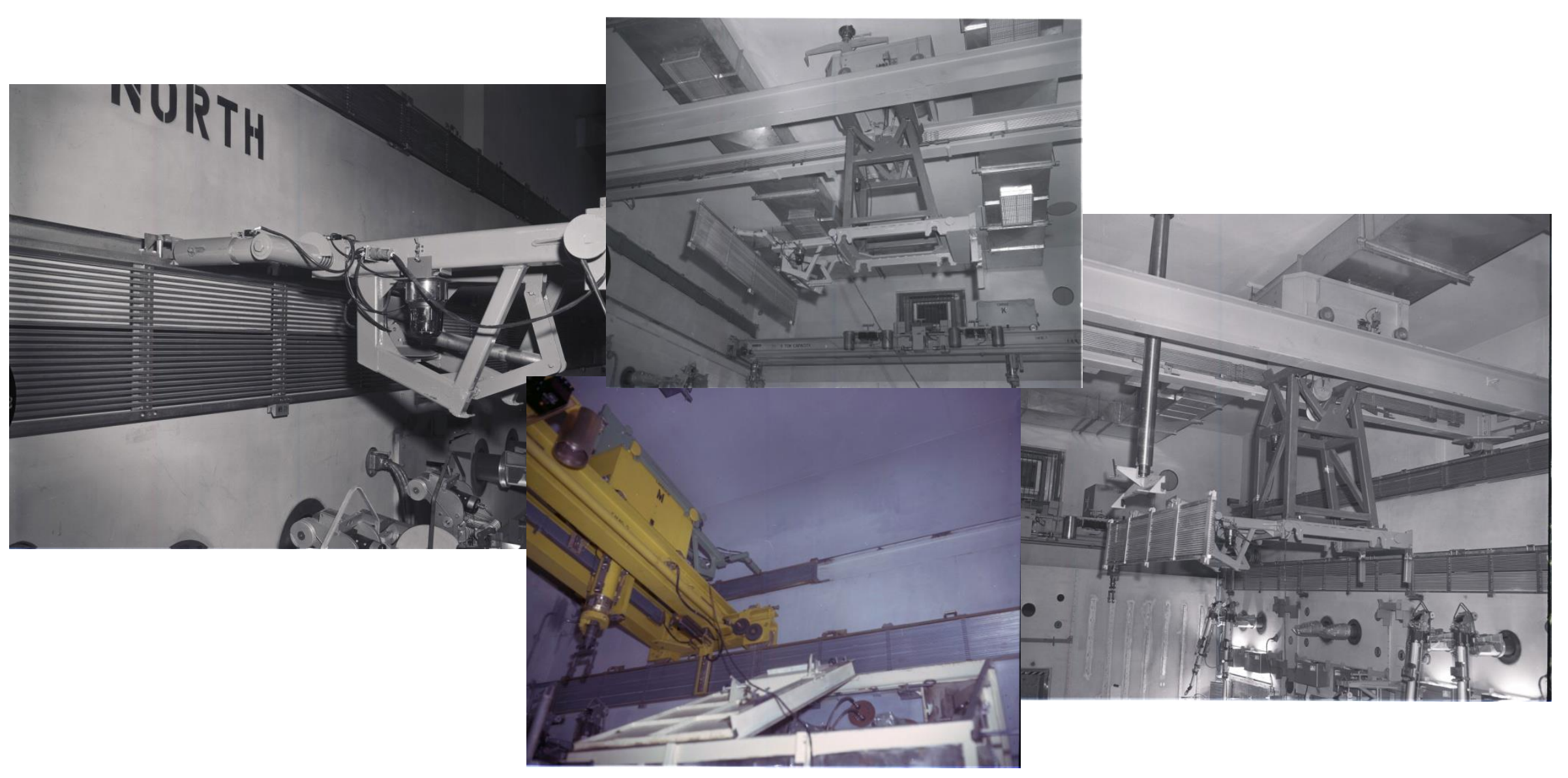




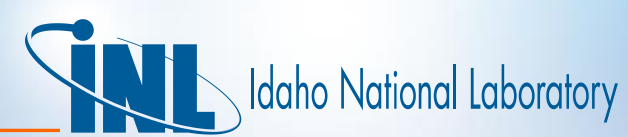

\section{Maintenance Support Systems/Areas}

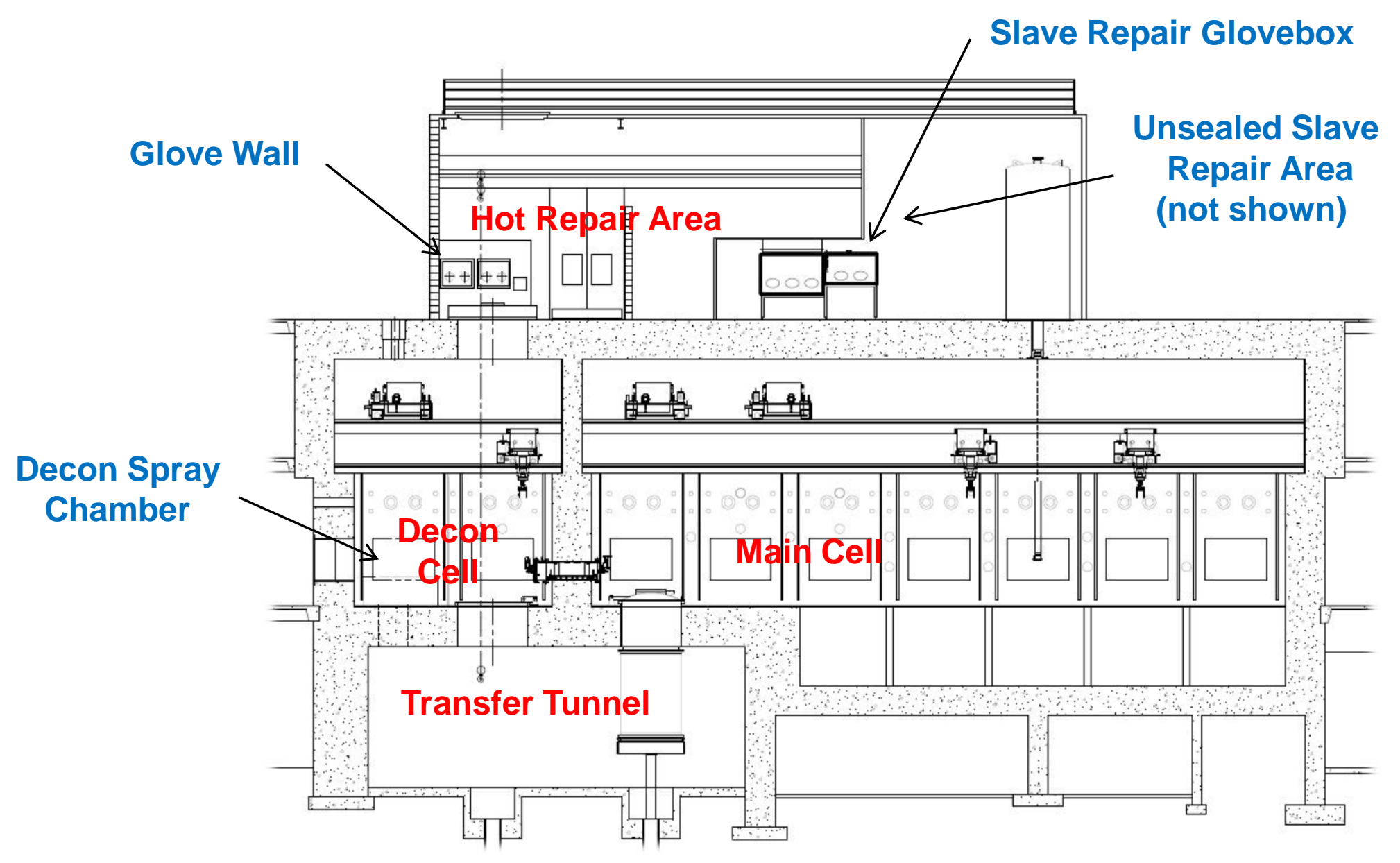




\section{Maintenance Support Systems/Areas} (Continued)

- Decon Spray Chamber (DCS)

- High pressure spray system to decontaminate slave arms.

- Has a rotating platform for accessing entire item.

- Slave arms are decontaminated using the DSC.

- Crane and EM carriages and trolleys are not typically washed. Remote wipe-down and contact decon on the HRA are usually employed.

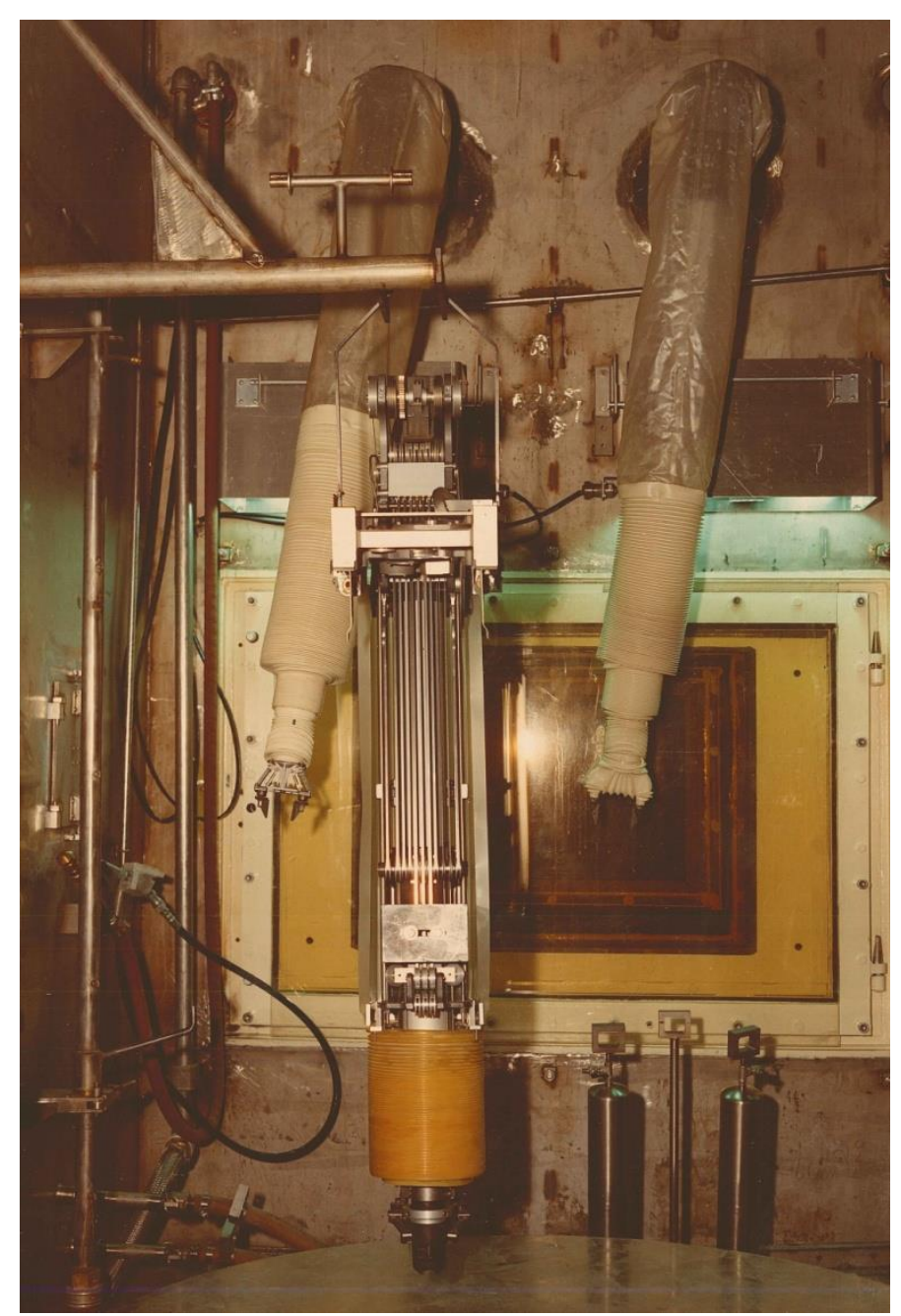




\section{Maintenance Support Systems/Areas (Continued)}

- Repair Areas

- Suited Repair Areas/Hot Repair Areas for contact maintenance

- Located near the decon cell. Allows for checkout of equipment for integrated testing

- Glove walls for repair of small components after removal from the equipment

- Operation of equipment for checkout prior to returning the component to the cell.

- Test manipulator seal tubes for checkout of manipulators prior to returning to service.

- Storage of manipulator slave arms for repair in the glove box and staging prior to transfer into the cell.

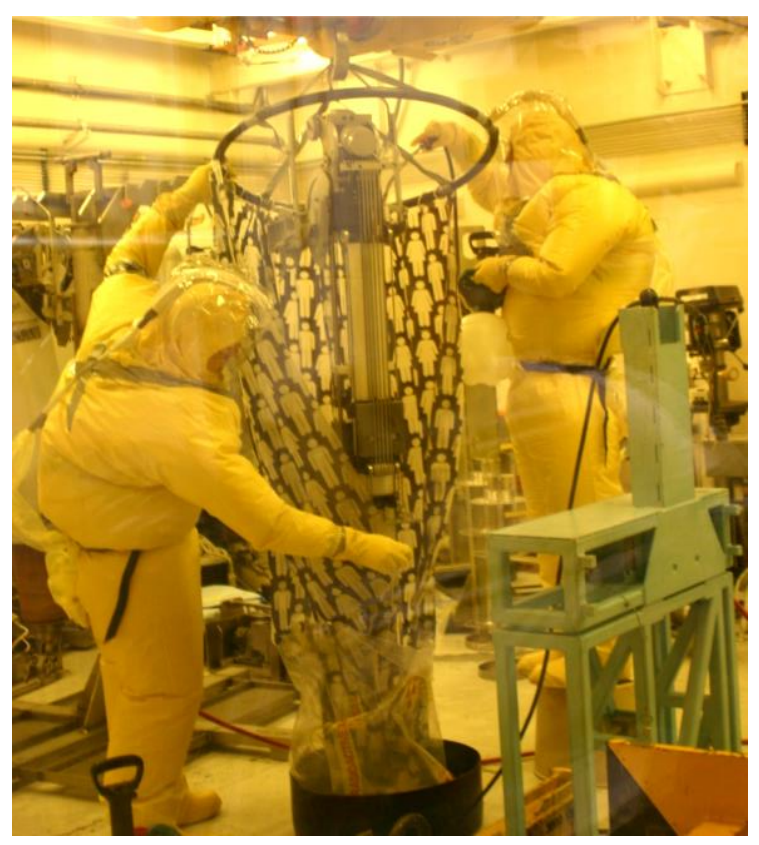




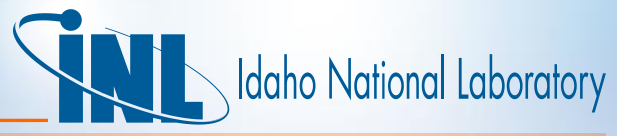

\section{Maintenance Support Systems/Areas (Continued)}

- Slave Repair Glove Box

- Connected to the HRA for loading and unloading

- Fixtures for holding slave arm in position for repairs

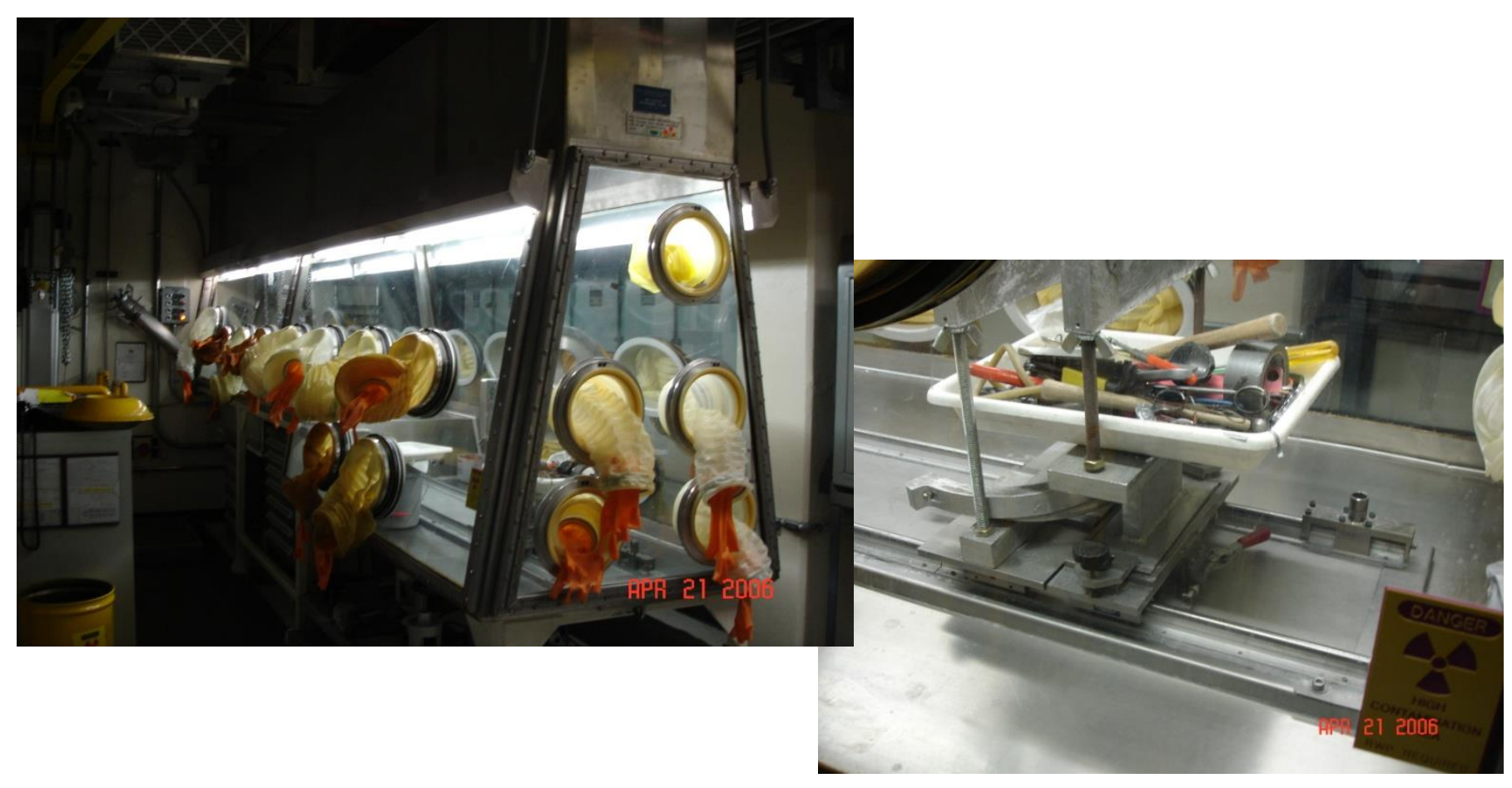




\section{Maintenance Support Systems/Areas (Continued)}

- Unsealed Slave Repair Room

- Room which the manipulator is loaded similar to the normal installation

- Room is entered as a suited repair area for hands on repairs to the slave end. 


\section{Maintenance Support Systems/Areas (Continued)}

- Mockup Area

- Specialized tool development for maintenance and recovery

- Qualification of tooling prior to deployment

- Operator/Technician Training

- Qualification/Testing of modifications to handing equipment.
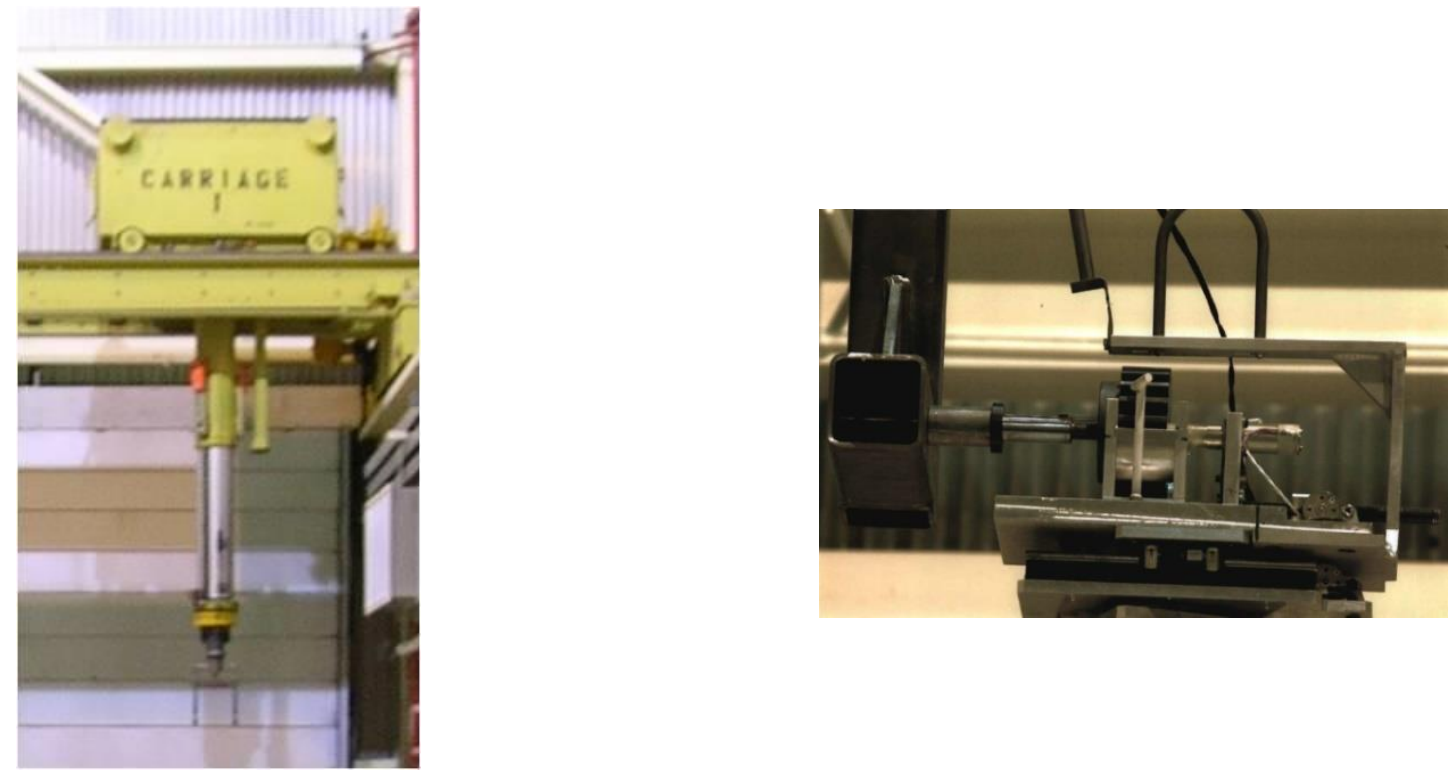


\section{Maintenance Support Systems/Areas (Continued)}

- Repair Equipment

- Seal Tube/Feed-through change-out

- The glove box is coupled to the wall via sleeving bagging ring. The sleeving and glove box provides a barrier for contamination control and cell atmosphere.

- Maintenance and repair of the seal tube is normally performed in another location.

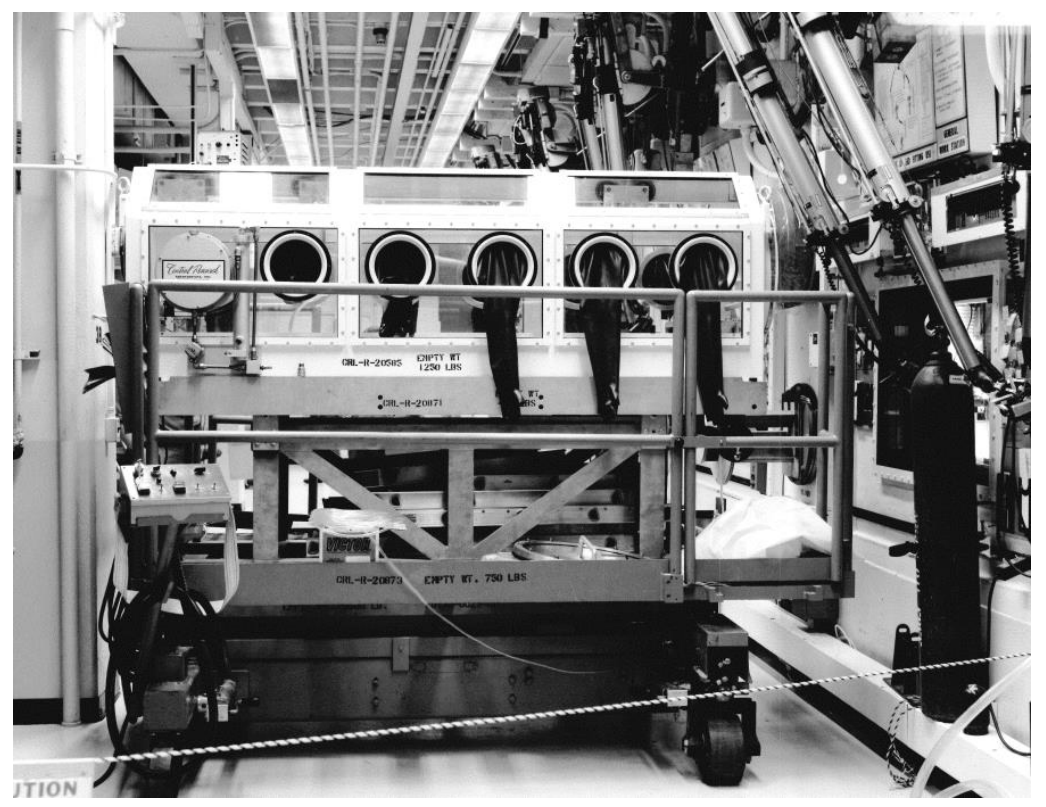




\section{Maintenance Support Systems/Areas (Continued)}

- Miscellaneous

- Spare master arm slave arms and unsealed manipulators.

- Manipulator Storage for spare master arms and unsealed manipulators.

- In-cell storage for slave arms.

- Hot Repair Area storage for slave arms (glove box staging)

- Spare Parts- Manipulator and overhead handling equipment spares are essential to timely corrective maintenance

- Preventative Maintenance for early detection of repairs/problems

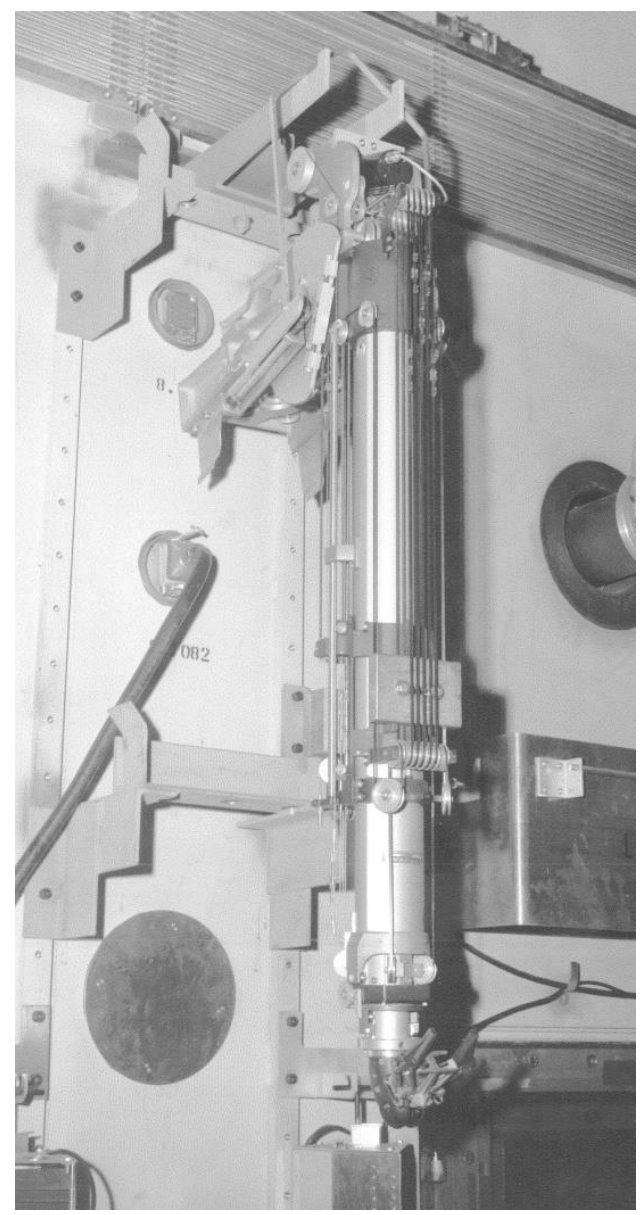




\section{Summary}

- Modular concept is important for reduction of facility downtime from equipment failures

- A robust spare system and sufficient number of spare units reduces delays in equipment repairs.

- Design for efficient decontamination of equipment is important for the reduction of worker dose and equipment repair time.

- A considerable amount of space dedicated for maintenance is necessary.

- Suited worker accessibility must be considered in design. 